\title{
Groundwater connectivity of a sheared gneiss aquifer in the Cauvery River basin, India
}

\author{
Sarah L. Collins ${ }^{1} \cdot$ Sian E. Loveless ${ }^{2} \cdot$ Sekhar Muddu $^{3,4} \cdot$ Sriramulu Buvaneshwari ${ }^{3,4} \cdot$ Romesh N. Palamakumbura $^{1}$. \\ Maarten Krabbendam ${ }^{1}$ • Dan J. Lapworth ${ }^{2}$. Christopher R. Jackson ${ }^{5}$. Daren C. Gooddy ${ }^{2} \cdot$ Siva Naga Venkat Nara $^{3}$. \\ Somsubhra Chattopadhyay ${ }^{6} \cdot$ Alan M. MacDonald $^{1}$
}

Received: 13 November 2019 / Accepted: 3 March 2020 / Published online: 8 April 2020

(C) British Geological Survey 2020

\begin{abstract}
Connectivity of groundwater flow within crystalline-rock aquifers controls the sustainability of abstraction and baseflow to rivers, yet is often poorly constrained at a catchment scale. Here groundwater connectivity in a sheared gneiss aquifer is investigated by studying the intensively abstracted Berambadi catchment $\left(84 \mathrm{~km}^{2}\right)$ in the Cauvery River Basin, southern India, with geological characterisation, aquifer properties testing, hydrograph analysis, hydrochemical tracers and a numerical groundwater flow model. The study indicates a well-connected system, both laterally and vertically, that has evolved with high abstraction from a laterally to a vertically dominated flow system. Likely as a result of shearing, a high degree of lateral connectivity remains at low groundwater levels. Because of their low storage and logarithmic reduction in hydraulic conductivity with depth, crystalline-rock aquifers in environments such as this, with high abstraction and variable seasonal recharge, constitute a highly variable water resource, meaning farmers must adapt to varying water availability. Importantly, this study indicates that abstraction is reducing baseflow to the river, which, if also occurring in other similar catchments, will have implications downstream in the Cauvery River Basin.
\end{abstract}

Keywords Crystalline rocks $\cdot$ Conceptual models $\cdot$ Fractured rocks $\cdot$ India $\cdot$ Hydrochemistry

Electronic supplementary material The online version of this article (https://doi.org/10.1007/s10040-020-02140-y) contains supplementary material, which is available to authorized users.

Sarah L. Collins

sarcol@bgs.ac.uk

1 British Geological Survey, The Lyell Centre, Edinburgh EH14 4AP, UK

2 British Geological Survey, Maclean Building, Crowmarsh Gifford, Wallingford OX10 8BB, UK

3 Department of Civil Engineering, Indian Institute of Science, Bangalore, Karnataka 560012, India

4 Indo-French Cell for Water Sciences, Indian Institute of Science, CNRS, IRD, INRA, UPS, Bangalore, India

5 British Geological Survey, Environmental Science Centre, Keyworth NG12 5GG, UK

6 Ashoka Trust for Research in Ecology and the Environment, Bangalore, Karnataka 560064, India

\section{Introduction}

Despite limited productivity, crystalline-rock aquifers play an important role in catchment hydrology (Ofterdinger et al. 2019), capable of providing domestic water supplies (Chilton and Foster 1992) and larger supplies for irrigation or towns (Maurice et al. 2019) as well as sustaining baseflow to rivers and aquatic ecosystems (Comte et al. 2019). Crystalline-rock aquifers are particularly important in India, as crystalline rocks underlie two-thirds of the country (Mukherjee et al. 2015) and groundwater is widely abstracted from crystalline aquifers for irrigation. The development of affordable drilling enabled groundwater to play a fundamental role in the Indian green revolution (Shah et al. 2003) and by 2010 groundwater abstraction was estimated to comprise more than $60 \%$ of all irrigation (World Bank 2010). The sustainability of abstraction and its impact on surface water is contested in Indian crystalline-rock aquifers: there is some evidence from groundwater monitoring boreholes and satellite measurement of Earth's gravity that groundwater levels are not declining (Tiwari et al. 2011) or that they are declining 
in only $22-36 \%$ of wells (Sishodia et al. 2016), but others caution unintentional bias in monitoring (Hora et al. 2019). Notwithstanding, there is considerable evidence of problems in individual catchments with falling groundwater levels and periodic loss of groundwater baseflow to rivers (e.g. Maréchal et al. 2006; Perrin et al. 2011a). At a larger scale, loss of baseflow has been hypothesised as a major factor in reduced river flows such as in the Arkavathy River basin $\left(4,253 \mathrm{~km}^{2}\right)$, west of Bangalore, where the drying of the river can be attributed to neither precipitation nor potential evapotranspiration (Srinivasan et al. 2015; Penny et al. 2018).

Connectivity of groundwater is controlled by the variability of aquifer properties in three dimensions, and in crystalline rocks aquifer properties are particularly heterogeneous. Weathered crystalline-rock aquifers generally consist of numerous zones, which are distinguished based on the degree of weathering (Acworth 1987; Chilton and Foster 1995; Wyns et al. 2004; Dewandel et al. 2006; Lachassagne et al. 2011). For this study, the aquifer is described in three zones: an upper saprolite, a lower saprock and, underneath, fresh basement. The term "saprock" is used to describe the part of the weathering profile that generally retains the original bedrock structure, whereas the "upper saprolite zone" is used to describe the part of the weathering profile where the original bedrock structure is no longer visible. The saprolite layer has a low effective porosity and hydraulic conductivity due to the prevalence of clay weathering products; the saprock layer comprises dense horizontal fractures with significant hydraulic conductivity; and the fresh basement has local permeability and porosity in fractures, which generally decrease in number with depth (Dewandel et al. 2006). Where groundwater is not exploited, crystalline-rock aquifers can contribute significantly to baseflow (e.g. Kosugi et al. 2006; Cai and Ofterdinger 2016; Comte et al. 2019; Zhao et al. 2019); however, as groundwater is increasingly abstracted and water levels fall, flow can become compartmentalised, depending on the presence and nature of fractures at depth (Perrin et al. 2011b; Guihéneuf et al. 2014; Alazard et al. 2016).

In this study groundwater connectivity is investigated across a catchment underlain by extensively sheared gneiss and highly stressed by abstraction. The strength of this work lies in the wide range of hydrogeological techniques employed and the data available for the catchment: geological characterisation, widespread aquifer properties testing, hydrograph analysis and the use of hydrochemical tracers. A numerical transect model is then developed, calibrated and used to explore the impact of declining groundwater levels on connectivity. Three specific research questions are addressed: (1) How has the geology impacted the development of 3D aquifer properties of the sheared gneiss? (2) How has groundwater connectivity in the catchment evolved and how does this impact on baseflow? (3) How does groundwater throughout the catchment respond to abstraction and the seasonal monsoon cycle?

\section{Materials and methods}

A concise description of the geological and hydrogeological methods and groundwater modelling are provided below and summarised in Table 1. Further information is provided in the electronic supplementary material (ESM1).

\section{Study area}

The study was conducted in the Berambadi catchment $\left(84 \mathrm{~km}^{2}\right)$, part of the Kabini Critical Zone Observatory and a tributary of the Cauvery River (Fig. 1; IFCWS 2019; IISc 2019). The Cauvery River drains a large proportion of peninsular India, supporting more than 31 million people (CWC -NRSC 2014), including the major cities of Bangalore and Chennai. In recent years there have been considerable pressures on water resources in the basin, with disagreements over their apportionment (Sivakumar 2011; Vanham et al. 2011).

The Berambadi catchment comprises reserved forest, agricultural land and several small villages. All investigations were carried out in the highly cultivated part of the Berambadi catchment, downstream of the forest. Biophysical variables have been intensively monitored in the catchment since 2009 (Sekhar et al. 2016; Tomer et al. 2015). The Berambadi is a west-east-oriented catchment towards the headwaters of the Cauvery River. The majority of the agricultural land lies between $760-850 \mathrm{~m}$ above sea level (asl) and hills bordering the catchment are between 900 and 1,100 $\mathrm{m}$ asl, rising up to 1,450 $\mathrm{m}$ in the Gopalaswamy Hills to the south. The catchment is part of the Mysore Plateau, underlain by the Western Dharwar Province of the Dharwar craton

Table 1 Summary of field investigations

\begin{tabular}{ll}
\hline Field investigation & Purpose \\
\hline $\begin{array}{l}\text { Geological/hydrogeological } \\
\text { Fracture measurements at } \\
\text { outcrops/quarries } \\
\text { Piezometric maps } \\
\text { Specific capacity tests }\end{array}$ & $\begin{array}{c}\text { Quantify fracture density and } \\
\text { orientation } \\
\text { Assess lateral connectivity } \\
\text { Estimate transmissivity and any spatial } \\
\text { or depth-dependent variation in } \\
\text { transmissivity }\end{array}$ \\
$\begin{array}{lc}\text { Single-borehole dilution tests } & \text { Assess density and depth of flowing } \\
\text { fractures }\end{array}$ \\
$\begin{array}{l}\text { Groundwater chemistry/residence times } \\
\text { Isotopes/inorganic elements }\end{array}$ & $\begin{array}{c}\text { Assess lateral vs. vertical connectivity } \\
\text { and recharge }\end{array}$ \\
CFCs and SF & Determine groundwater residence times \\
Numerical modelling & \\
Transect model & Test hydrogeological conceptual model \\
\hline
\end{tabular}


(a)

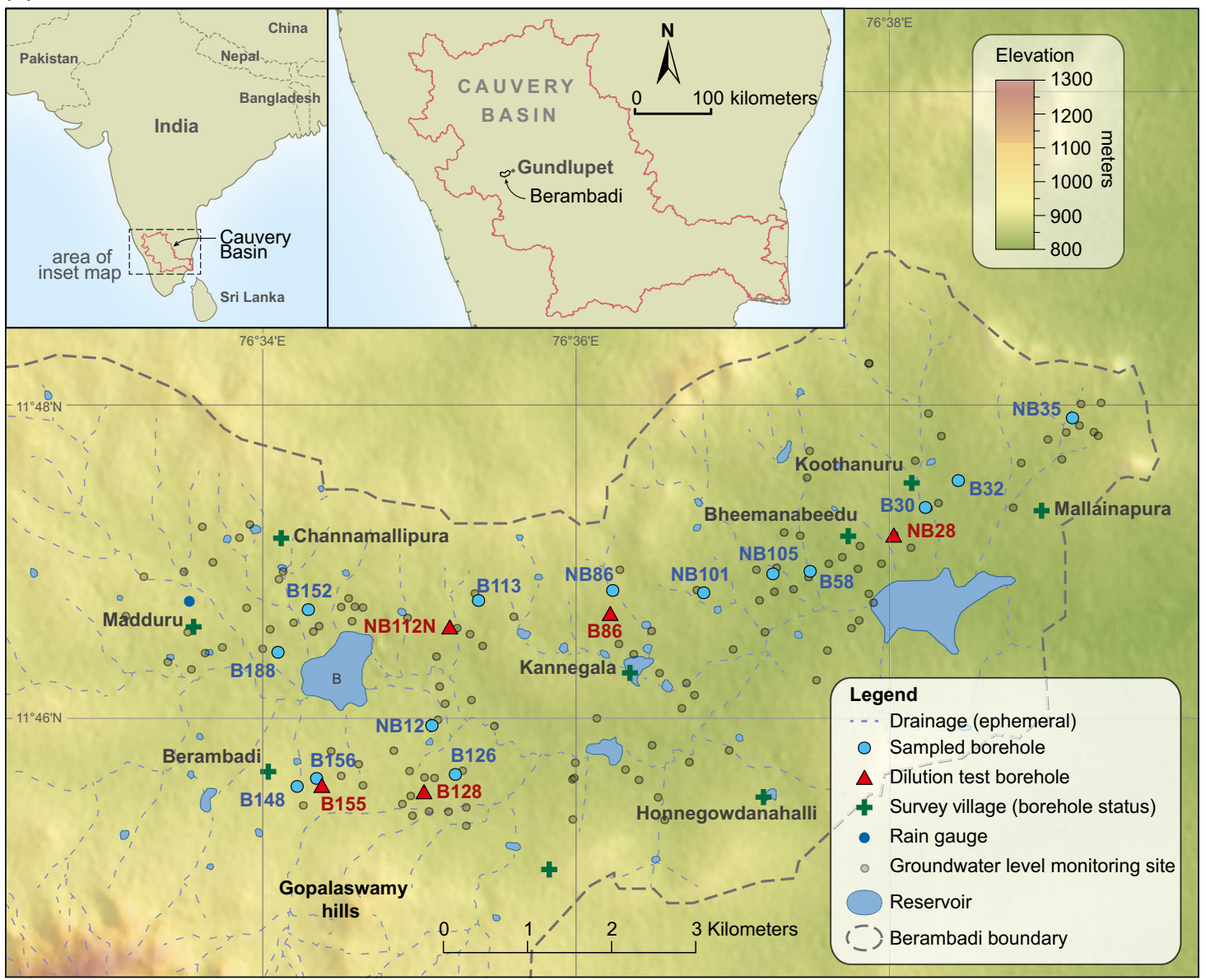

(b)

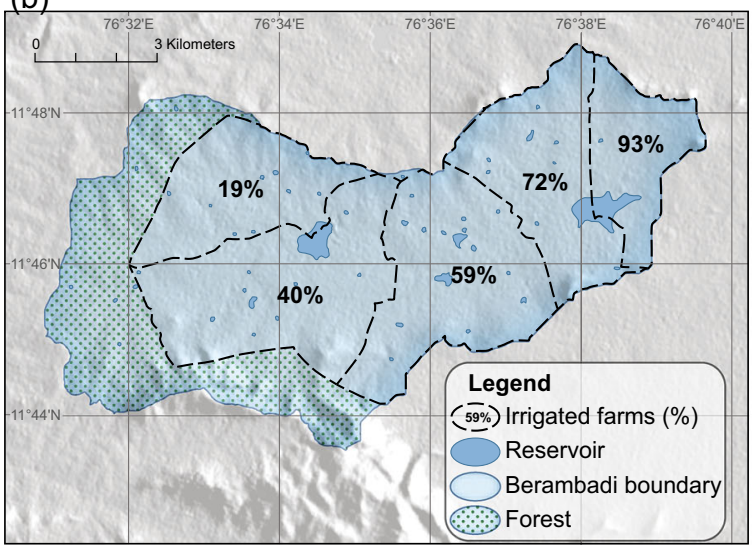

Fig. 1 a The cultivated area of the Berambadi catchment used in this work. Inset shows Cauvery Basin and Berambadi catchment within peninsular India. B Berambadi tank. b Percentage of farms that use irrigation (Robert et al. 2017). c Mean monthly temperature and rainfall

of Archaean-Paleoproterozoic age (e.g. Naqvi and Rogers 1987). The craton comprises three broad rock categories: gneisses (tonalite, trondhjemite and granodiorite) of the Peninsular Gneiss, meta-sediments and meta-igneous rocks (schist, meta-sandstone, amphibolites) of the Dharwar Schists (supra-crustals), and to the east the granite of the Closepet

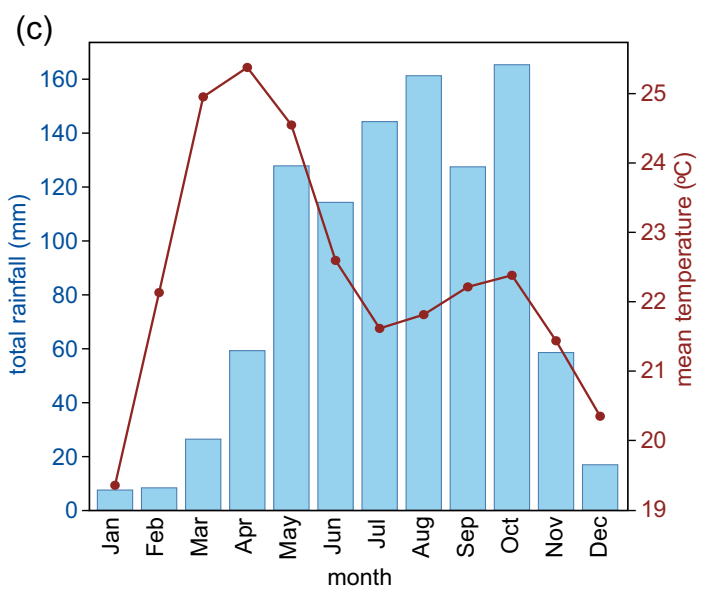

at rain gauge 1 (shown in the next figure) 2005-2018. Contains topographic elevation data from NASA (Jarvis et al. 2008), Cauvery Basin from World Wildlife Fund HydroSHEDS and data from digital chart of the world (ESRI)

batholith belt (Rao 1962; Meert et al. 2010). The catchment itself is made up of amphibolite- to granulite-facies metamorphic rocks, which have undergone local retrogressive metamorphism. Small hills in the area are thought to be remnant interfluves, which are made up of quartzite and are therefore chemically stable and less susceptible to weathering. Dykes ranging from 
0.5 to $1.5 \mathrm{~km}$ in length trend $\mathrm{E}-\mathrm{W}$ (Sekhar et al. 2016). Boreholes tend to be cased for a few metres through the softer saprolite and open-hole through the remainder of the depth.

The Berambadi catchment has a tropical savannah climate (Peel et al. 2007) with rainfall averaging $800 \mathrm{~mm} /$ year, but varying from $900 \mathrm{~mm} /$ year in the west to less than $700 \mathrm{~mm} /$ year in the east (Fig. 1c). Mean annual potential evapotranspiration is $1,100 \mathrm{~mm} /$ year (Sekhar et al. 2016; Robert et al. 2017). The majority of rain falls in the southwest monsoon from June to September (Kharif), which is also the main growing season. Crops grown in Kharif (June to September) and Rabi (October to January) seasons are a mixture of rain fed and irrigated (Sekhar et al. 2016; Robert et al. 2017). The type of crops grown depends strongly on local markets and recent climatic conditions.

The Berambadi River is ephemeral, although the local communities observe that parts of it used to be perennial in the past. There are a number of small- to medium-sized rainfed reservoirs, known as "tanks", in the catchment, the largest of which is the Berambadi tank (see Fig. 1a). To the authors' knowledge, the other tanks in the catchment are usually dry, but can fill up after a heavy monsoon such as in 2018. The Berambadi tank contained water for almost the entire monitoring period (2011-2018), drying only between December 2016 and April 2017. Field bunds, designed to prevent runoff and encourage infiltration, are a common feature of the agricultural land.

The first boreholes for groundwater irrigation in the Berambadi catchment were drilled in the 1960s and the number has increased rapidly since the 1990s, increasing from east to west across the catchment. This has been accompanied by an increase in borehole depth due to improved technology (Robert et al. 2017). Agriculture in the Berambadi is now heavily reliant on a dense network of boreholes and dependence on irrigation increases from west to east (Fig. 1b; Robert et al. 2017). The Central Ground Water Board (CGWB) estimate groundwater abstraction to be $70 \mathrm{~mm} /$ year for the Gundlupet Taluk, in which the Berambadi lies (CGWB 2008). The Berambadi tank is the only reliable source of surface water irrigation in the catchment, supplying nearby farms with water through a network of drainage channels.

\section{Geological and hydrogeological investigations}

Outcrop and quarry observations were made across the Berambadi catchment to identify the nature of geological units and fractures. Fracture topology was assessed using georeferenced photographs in ArcGIS, following the method of Palamakumbura et al. (2019). The uniformity of groundwater level fluctuations and the spatial correlation of groundwater levels were used as indicators of groundwater connectivity. From May 2010 to December 2018, groundwater depth (below ground) was measured monthly at 205 boreholes across the catchment. Maps of groundwater elevation and groundwater depth range (2010-2018) were produced through interpolation using ordinary kriging in ArcGIS. The uniformity of groundwater level fluctuations was quantified by calculating Spearman's rank correlation coefficients for 119 complete groundwater level time series (2010-2018); and the spatial correlation of groundwater levels was analysed by generating variograms with ArcGIS for piezometric head at low (May 2017) and high (May 2010) water levels. The latter method was also used by Guihéneuf et al. (2014) as an indicator of the connectivity of granite in peninsular India.

Borehole yield was estimated by measuring the time taken to fill a bucket $(10 \mathrm{~L})$ with water pumped from a borehole. The test was repeated three times for each borehole and an average taken. Specific capacity was calculated as the volume of the bucket divided by the average time taken to fill it and the drawdown. As the boreholes were in continual use when the test was carried out, only the pumped water level was recorded and the resting water level was taken from monthly measured groundwater depth (described previously). Borehole yield was measured in 92 boreholes in 2012 and in 81 of the same boreholes in 2017. Percentiles (10, 25, 50, 75 and 90th) of specific capacity were determined for groundwater level depths of $<10 \mathrm{~m}, 10-20 \mathrm{~m}, 20-40 \mathrm{~m}$ and $>40 \mathrm{~m}$, and hydraulic conductivity $(K)(\mathrm{m} /$ day) approximated using the empirical equation of Logan (1964):

$K=1.22 \frac{Q}{\mathrm{~s} \times B}$

where $Q$ is borehole yield ( $\mathrm{m}^{3} /$ day), $s$ is drawdown ( $\left.\mathrm{m}\right)$ and $B$ is the saturated thickness (m). Specific capacity was normalised to saturated borehole depth to account for variations in contributing aquifer thicknesses. In addition, borehole data collected from farm surveys (Robert et al. 2017) were assessed to determine the percentage of 'working' boreholes (i.e. described by the farmer as producing water) in nine surveyed villages and failure rate was compared with depth to groundwater. The sample size for each village ranged between 14 and 267 boreholes.

Single-borehole dilution tests (SBDTs) involve injecting a saline solution throughout a borehole water column and measuring the salinity profile in the borehole until the concentration returns to background salinity (Maurice et al. 2011). Five SBDTs were carried out in the catchment in order to identify the depth distribution of fractures in the saturated aquifer. These boreholes had been abandoned due to low yields, thus biasing results towards poorer yielding boreholes or those with deeper groundwater. Flow rates at particular fracture locations were determined with the Python package DISOLV (Collins and Bianchi 2020), a one-dimensional (1D) advection-dispersion numerical model for interpreting SBDT data. 


\section{Groundwater chemistry and residence times}

Groundwater chemistry was sampled under post-monsoon (September/October 2017) and pre-monsoon (April/ May 2018) conditions. Inorganic (major, minor and trace) elements, stable isotopes $\left(\delta^{18} \mathrm{O} / \delta^{2} \mathrm{H}\right)$, and field parameters $(\mathrm{pH}$, temperature, $\mathrm{HCO}_{3}$ and $\mathrm{DO}$ ) samples were collected at 14 boreholes across the catchment (Fig. 1a), following purging of boreholes and stable readings for field parameters. Rainfall stable isotope data from Penny et al. (2019) were used in the analysis and this data set was supplemented by additional bulk rainfall samples collected for stable isotope analysis approximately monthly from 31 August 2017 until October 2018 at three locations across the catchment. Rainfall samples were collected using a totaliser with a tube and "dip-in" design suitable for the climate of India which minimise evaporative effects (IAEA/GNIP 2014). Ten CFC and $\mathrm{SF}_{6}$ samples were collected unfiltered, and without atmospheric contact, in sealed containers by the displacement method of Oster et al. (1996). These samples could only be taken from selected boreholes where there was no evidence of air intake in the rising main. All chemical analysis was undertaken at BGS geochemistry and groundwater tracer laboratories in the UK. Stable isotope results are reported as a deviation from Vienna Standard Mean Ocean Water (vs. VSMOW) in per mil (\%o) difference using delta $(\delta)$ notation. Deuterium excess (d-excess) for rainwater and groundwater samples was calculated using the following equation $\delta^{18} \mathrm{O}-8$. $\delta^{2} \mathrm{H}$ (Dansgaard 1964).

\section{Numerical transect model}

A 1D finite difference groundwater model, coded in Python, was applied to a flow path approximately north-west to south - east through the catchment, broadly following the valley bottom (Fig. 2). The model was used as an exploratory tool, rather than for prediction. An equivalent porous medium model was used, in which the parameterisation of transmissivity was constrained using data from the 173 specific capacity tests undertaken (see 'Geological and hydrogeological investigations'). First, a conceptual model of the heterogeneity of the system was tested by examining whether historical observations could be reproduced; and, secondly, how this may change, if abstraction were reduced, was explored. A more detailed description of the model set up and uncertainties is given in ESM1. The western boundary of the transect, near to an observed groundwater mound (ring contour), was assumed to be no flow and, at the east boundary, groundwater head was set to the average observed groundwater level of three boreholes (all within $300 \mathrm{~m}$ of the end of the transect). A steadystate simulation using average rainfall (April 2010 to December 2018) was run first to provide initial heads for transient simulations. The sensitivity of the model to transmissivity and abstraction was tested using 50 simulations: comprising five different transmissivity profiles and 10 different abstraction rates. The five transmissivity profiles were derived from the transformation of specific capacity data (at the $10,25,50,75$ and 90 th percentiles) into transmissivity ( $T=1.22 \mathrm{Q} / \mathrm{s}$; Logan 1964): an exponential curve was fitted to each profile for input into the model. The 10 abstraction rates were taken at even intervals between $\pm 20 \%$ of reported annual abstraction (CGWB 2008).

Two parameters were calibrated in the steady-state model: a coefficient for translating rainfall into recharge and an abstraction gradient, which reflects increasing use of irrigation from west to east across the catchment (Fig. 1b). Recharge from return flow was not considered separately, but was instead assumed to be encompassed by the rainfall-recharge coefficient. This simplification means that recharge is limited in the summer, when rainfall is low, but little is grown in the summer, so irrigation return flow should also be low. Baseflow is generated only when groundwater levels rise above the land surface. The abstraction gradient was calibrated on the median transmissivity profile and then applied to all other model runs in the sensitivity analysis, whereas the recharge coefficient was calibrated for each model run (see ESM1). The steady-state simulations that produced average groundwater levels within the uncertainty limits of $80 \%$ of the groundwater level observations were run as transient simulations from April 2010 to December 2018. A sensitivity analysis was performed, first, on a depth-invariant specific yield, and, second, on an exponentially decreasing specific yield with depth.

Additional simulations were carried out with abstraction reduced to 0,25 and $50 \%$ of the reported annual mean (see ESM1). The abstraction gradient was retained from the original model and an average runoff coefficient for each transmissivity profile was used. In using the runoff coefficients from the original model for the reduced abstraction scenarios, irrigation return flow is neglected. These simulations are, therefore, not quantitative predictions of baseflow and lateral groundwater flow, but rather indicative of how the groundwater flow regime and the catchment water balance change, as abstraction is decreased. In using a 1D model, it is assumed that the groundwater flow direction will change little, if abstraction were reduced. This is a reasonable assumption, given the transect follows the natural drainage line. Owing to the intensity of fracturing in all directions in the shear zones (see 'Geological observations'), the orientation of the shear zones is assumed to have no effect on the direction of groundwater flow.

\section{Results}

Results of the hydrogeological investigations and numerical groundwater modelling are summarised in the following section. Further information is included in ESM1. 
Fig. 2 Transect for numerical model through the Berambadi catchment. Observation boreholes are those used for model comparison. Groundwater level elevation ( $\mathrm{m}$ above sea level)

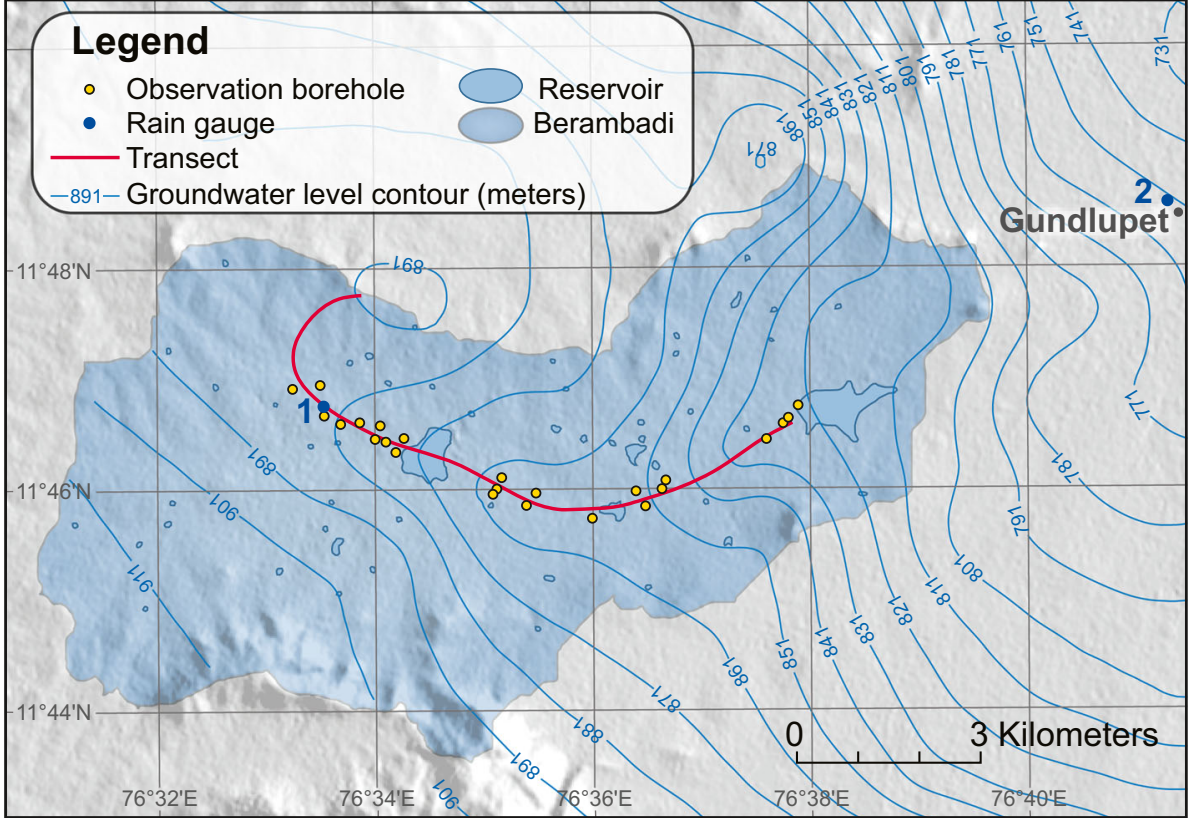

\section{Geological observations}

The Berambadi catchment consists of both massive and sheared gneisses that are compositionally mainly grey felsic gneiss with local mafic, amphibolite enclaves or layers. Foliation (gneissosity) in the massive gneisses is moderately developed with a typically wispy layering of felsic/ intermediate composition and locally more distinct mafic layers. Outcrop observations indicate well-developed subhorizontal sheet joints broadly parallel to the ground surface, which increase in abundance close to the surface (with spacing of 1-2 m) (Fig. 3a) and have an anastomosing pattern, potentially providing a well-connected fracture network in the top 5-10 m. On occasion, fractures that connect to the surface start to clay infill, which is likely the result of chemical weathering along the open fracture. Below this upper fractured zone, background jointing comprises both vertical and horizontal fractures in a broadly orthogonal system, with a slightly wider fracture spacing of $1-3 \mathrm{~m}$ and a density ca. $0.5-2 \mathrm{~m}^{-1}$, observed down to ca. $30 \mathrm{~m}$ below the surface in quarries. Horizontal fractures in the upper zone can be several metres in length (from 1 to $>12 \mathrm{~m}$ ), whereas the vertical connecting fractures tend to be centimetres in length.

The sheared gneisses possess a strongly to very strongly developed gneissosity (Fig. 3b). In most outcrops, the gneissic foliation was steep to subvertical, although it is locally inclined. In the Berambadi catchment, sheared gneisses occupy $40-70 \%$ of the rock and foliation swings from an $\mathrm{E}-\mathrm{W}$ trend in the south towards a more NE-SW or N-S trend north of the town of Gundlupet, consistent with the shear fabrics mapped by Chardon et al. (2008). Supracrustals (schistose amphibolite, garnet-mica schist and psammite (metasandstone), with thinner or rarer units of quartzite and metalimestone (marble), commonly form local hills. Typically, the supracrustal rocks have a strong fabric due to a combination of bedding (sheared) and a strong schistose foliation. The overall foliation is broadly parallel to that in the sheared gneisses, which also conform broadly to the mapped shear fabrics of Chardon et al. (2008).

In the sheared gneiss and supracrustal rocks, fracturing is much more intense (fracture spacing of $<10 \mathrm{~cm}$ ). Foliationparallel fractures, usually steeply dipping, are particularly common, particularly along relatively weaker continuous
Fig. 3 Massive and foliated gneiss in the Beramabadi catchment: a gently inclined to subhorizontal fractures in upper part of massive gneiss at eastern edge of the catchment and $\mathbf{b}$ sheared gneiss
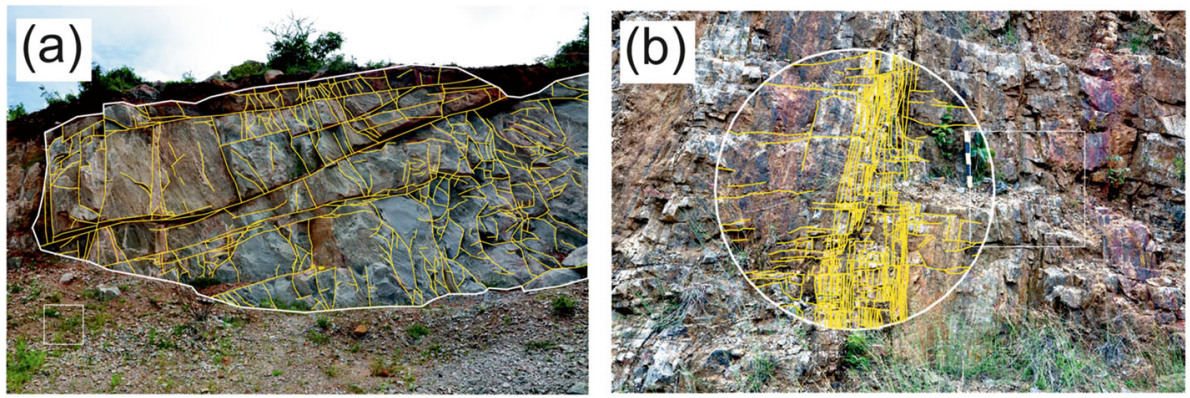
biotite-foliation planes (Fig. 3b). Where the spacing of the vertical fractures is less than $10-50 \mathrm{~cm}$, fractures normal to foliation appear to link the foliation-parallel fractures ("ladder fractures"). The fractures have broadly the same spacing as the foliation-parallel set, creating a dense orthogonal fracture network with approximately cubic blocks. Broadly speaking, the more intense the gneissic layering, the more dense the fracture network is. Within well-fractured, sheared gneiss, continuous horizontal sheet joints have not been observed. In general, the sheared fracture zones are parallel to the NE-SW foliation; however, this may vary somewhat at a site scale. The fracture zones are dominated by many relatively short fractures of $<10 \mathrm{~cm}$ up to $4 \mathrm{~m}$ in length. The fracture density within the fracture zones is significantly higher than the background gneiss but also highly variable within and between fracture zones from $0.7-18 \mathrm{~m}^{-1}$, reflecting their heterogeneous nature.

The regolith is locally variable in thickness $(1-5 \mathrm{~m})$ across the catchment. The lower saprock unit comprises fresh to heavily weathered blocks of gneiss in a clayey sand matrix, with properties similar to a friable rock. The saprolite upper unit comprises a clayey sand or gravel, with less consolidation, with occasional relict gneissose structures still present. In general, the lower saprock blocky unit is always present and 1-3 m thick, whereas the upper saprolite unit of clayey sand is present in the topographically lower and flatter parts of the catchment (typically $1-3 \mathrm{~m}$ thick), but generally absent or thin $(<0.5 \mathrm{~m})$ on slopes. This suggests that the upper, poorly consolidated unit is vulnerable to erosion by sheet wash.

\section{Groundwater levels}

Groundwater levels (2010-2018) show a distinct annual cycle, with a generally shallower water table during and after the monsoon (June-September) and deeper levels beforehand (Fig. 4a). The variability in annual monsoon rainfall, however, drives a striking inter-annual trend in groundwater level. Rainfall in 2018 was the highest recorded since the rain gauge (rain gauge 1 in Fig. 1a) was installed in 2003 and rainfall in 2016 the lowest, and this can be clearly observed in the response of the groundwater levels. Whereas in 2015 and 2016 groundwater levels dropped by up to $30 \mathrm{~m}$, in 2018, groundwater levels rose by up to $30 \mathrm{~m}$ (Fig. 4a). By November 2018, groundwater levels had recovered to pre-2010 levels in the west and centre of the catchment (Fig. 4a).

Across all monitored boreholes, there is a remarkable uniformity in groundwater level fluctuations (see Fig. 4a). Between 119 complete groundwater level time series (20102018), the median Spearman's rank correlation coefficient is 0.90 (25th percentile $0.85,75$ th percentile 0.95 ). Regional groundwater flow paths through the catchment remained almost completely unchanged during the monitoring period (see Fig. S4 of ESM1). A characteristic length ("range")-i.e. the distance beyond which there is no spatial correlation - cannot be determined for groundwater levels in May 2010 (shallow groundwater levels) nor in May 2017 (deep groundwater levels), although correlation is weaker in May 2017 than in May 2010 (Fig. 4c).

Depth to groundwater increases from west to east down the catchment (Fig. 4b), driven by increased abstraction in the east (Buvaneshwari et al. 2017; Robert et al. 2017). The range in groundwater levels over the monitoring period (2010-2018) increases with increasing mean depth to groundwater (Fig. 4d, see also Fig. S3 of ESM1). This relationship appears to become weaker from a depth of $\sim 30 \mathrm{~m}$, but is likely biased by a large number of wells that became dry, particularly in 2016 and 2017.

\section{Borehole specific capacity}

Figure 5a shows the spatial distribution of specific capacity per metre of saturated borehole, referred to as "normalised specific capacity", in 2012. Taking the specific capacity data across the two surveys of 2012 and 2017, there is a logarithmic decrease in median normalised specific capacity, and therefore hydraulic conductivity, with depth to rest water level (Fig. 5b). The probability of encountering high hydraulic conductivity (75th and 90th percentile profiles) decreases sharply with depth, but lower hydraulic conductivity values (25th and 10th percentile profiles) reduce more slowly with depth, showing that hydraulic conductivity can be much higher, but also more variable, at shallower depths. A survey of borehole functionality in 2015 conducted by Robert et al. (2017) reported that $58 \%$ of boreholes had failed and $9 \%$ had not worked since 2013. There is a strong correlation between mean groundwater level for the survey period (September 2014 to March 2015) and percentage of working boreholes (Fig. 5c), suggesting that borehole failure is largely a function of depth to groundwater.

\section{Single-borehole dilution tests}

The dilution profiles are shown in Fig. S5 of ESM1 and the interpreted fracture locations and flow rates are shown in Fig. 6. In two of the five boreholes, there was no (B155) or negligible (B128) groundwater flow; in the latter borehole, there appears to be a very weak inflow at $18 \mathrm{~m}$ below ground level (bgl), but the location of the outflowing fracture is not clear as the borehole did not fully dilute during the duration of the test (3 months). For the remaining three boreholes, fracture inflow and outflow locations and strengths were determined from calibration of the 1D transport model (Fig. 6; Fig. S6 of ESM1). Owing to low water levels at the time of the tests, only borehole B112 was saturated above $15 \mathrm{~m}$ bgl. In this borehole, crossflow in the top $3 \mathrm{~m}$ led to dilution down to $5 \mathrm{~m}$ bgl within a day. Similarly, cross-flow at the top of the water column in BH86 caused rapid dilution between 15 and $17 \mathrm{~m}$ bgl. Boreholes B86 
(a)

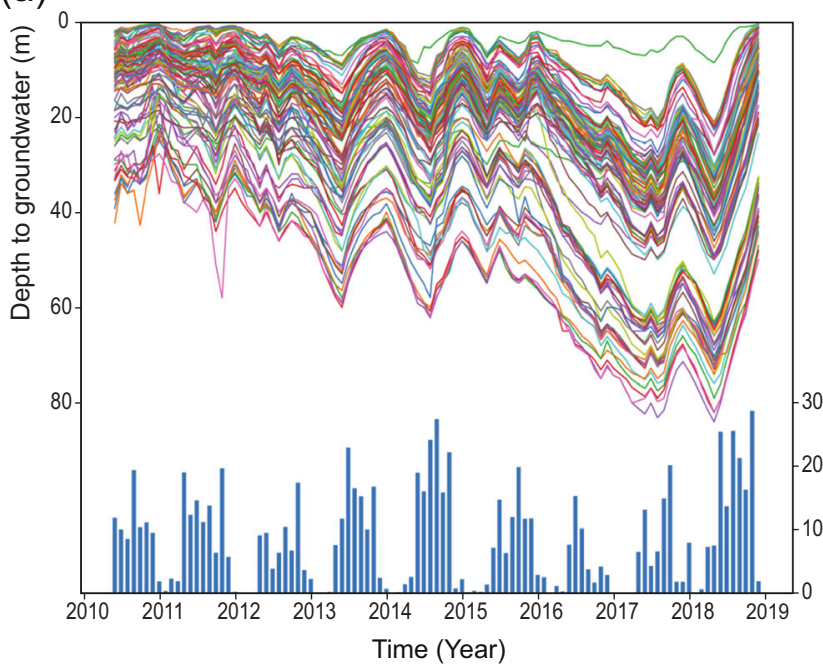

(c)

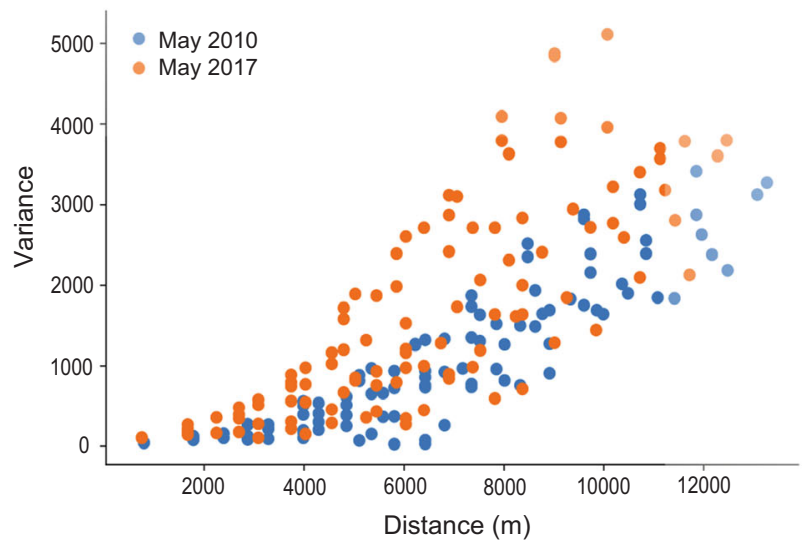

(b)

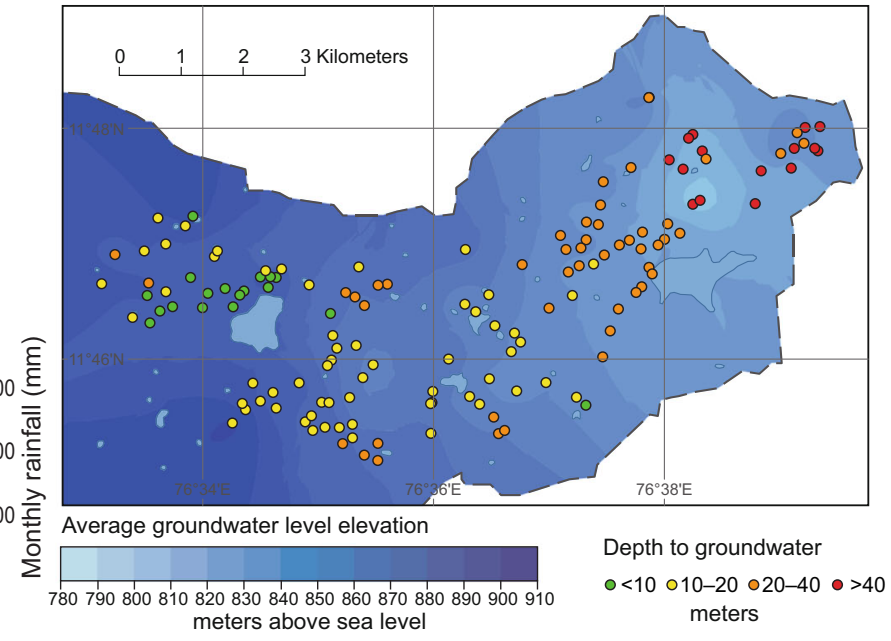

(d)

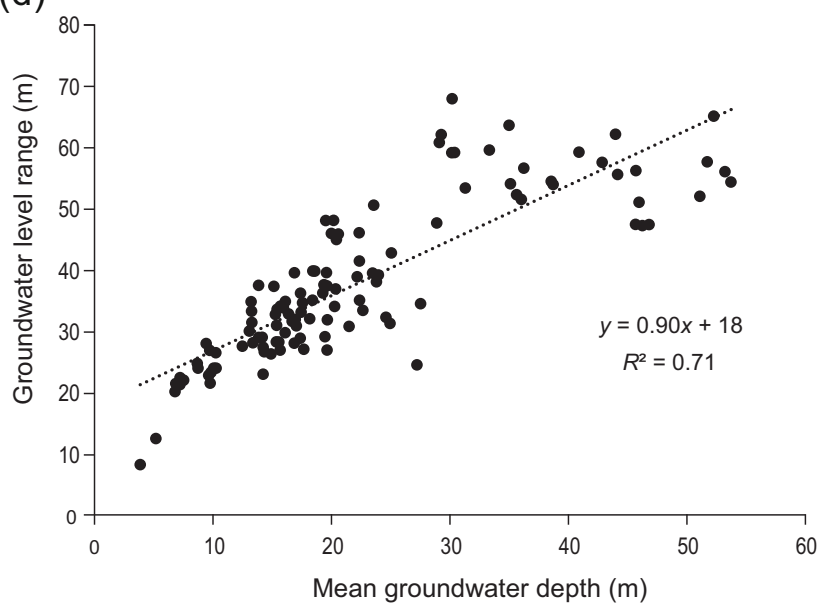

Fig. 4 a Monitored groundwater depth. b Measured mean depth to groundwater and kriged mean groundwater elevation (both 2010-2018). c Variogram of groundwater elevation at high (May 2010) and low (May 2017) water levels. d Mean groundwater depth vs. range (2010-2018)

and NB112 both show weak flow down the borehole (BH86, $0.03-0.14 \mathrm{~m}^{3} /$ day; NB112, $0.18-0.39 \mathrm{~m}^{3} /$ day). In borehole B86, there appears to be no flow below the fracture at $51.2 \mathrm{~m}$, and the very slow dilution below this point is most likely a result of diffusion. In contrast, borehole NB28 diluted quickly due to rapid flow $\left(5.5 \mathrm{~m}^{3} /\right.$ day $)$ down the borehole, predominantly from a fracture at $48.6-50.4 \mathrm{~m} \mathrm{bgl} \mathrm{to}$ a fracture at $93.8 \mathrm{~m}$ bgl. The downward movement of groundwater within the boreholes suggests a dominant downwards hydraulic gradient where fractures are connected.

\section{Hydrogeochemical tracers}

Groundwaters in the Berambadi catchment are characterised as predominantly $\mathrm{Ca}-\mathrm{Mg}$-Na-bicarbonate type with average TDS of $780 \mathrm{mg} / \mathrm{L}$ and values typically below $1,500 \mathrm{mg} / \mathrm{L}$. Summary hydrochemistry results for $\mathrm{NO}_{3}, \mathrm{Cl}$, stable isotopes and groundwater residence time tracers ( $\mathrm{CFCs}$ ) are shown in Fig. 7. Overall, only very minor changes in concentrations for major and trace elements were observed between the two sampling rounds. No reduction in $\mathrm{NO}_{3}$ concentrations is seen with increased borehole depth, Fig. 7a, (this is also the case for $\mathrm{Cl}$, stable isotopes and $\mathrm{CFCs}$ ). Nitrate in groundwater was found to exceed the WHO drinking water guideline value of $50 \mathrm{mg} / \mathrm{L}$ in all but four samples (Fig. 7a), with a maximum concentration $>400 \mathrm{mg} / \mathrm{L}$. Chloride and $\mathrm{NO}_{3}$ results show a weak positive correlation (Fig. 7a subplot) indicative of inputs to groundwater of both $\mathrm{Cl}$ and $\mathrm{NO}_{3}$ from fertiliser sources. Nitrate was also found to increase west to east across the catchment, consistent with the findings of Buvaneshwari et al. (2017).

$\mathrm{CFC}$ results are summarised in Fig. $7 \mathrm{~b}$ as a cross plot between CFC-12 and CFC-11. Spatial plots of CFC (and $\mathrm{SF}_{6}$ ) show no trend across the catchment (see ESM1 for details). There is a good overall agreement between the two CFC tracers, $r^{2}=0.6(p<0.001)$; however, the concentrations exceed expected modern recharge values in all but one sample. $\mathrm{SF}_{6}$ results are also found in excess of modern recharge values 
(a)

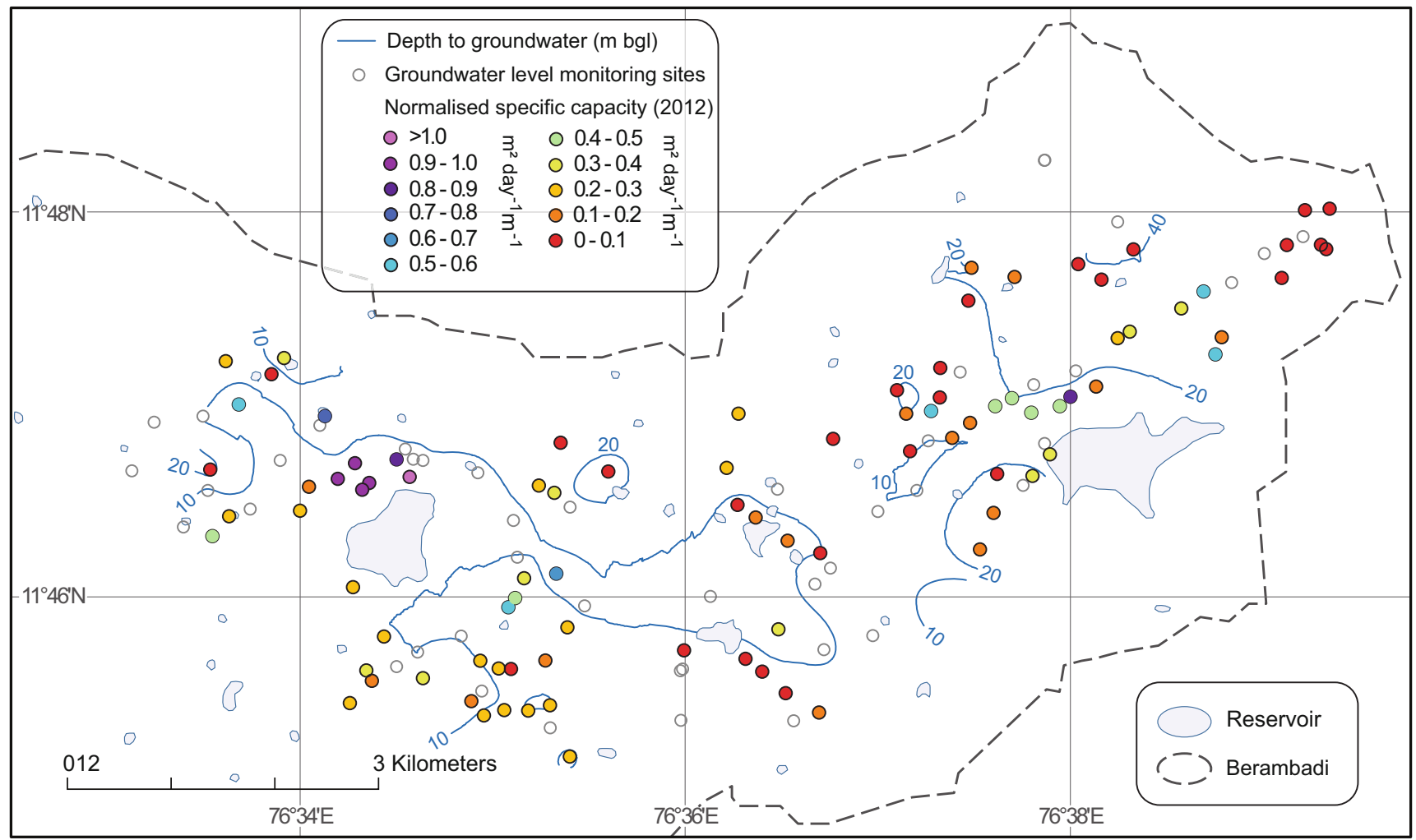

(b)

Hydraulic conductivity $\left(\mathrm{m} \mathrm{d}^{-1}\right)$

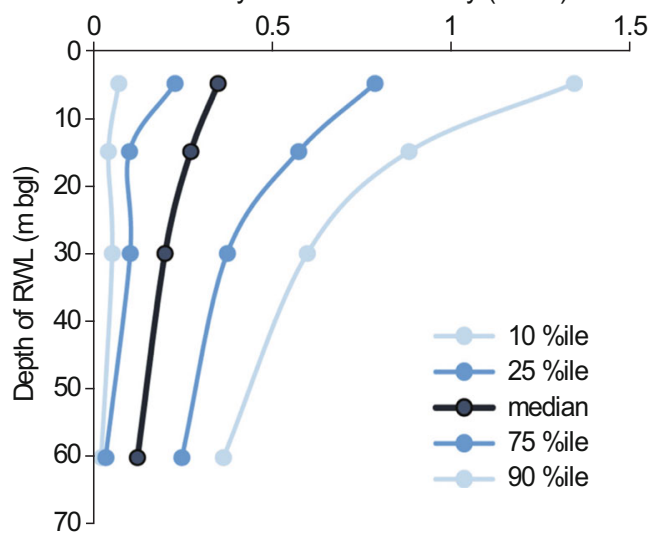

(c)

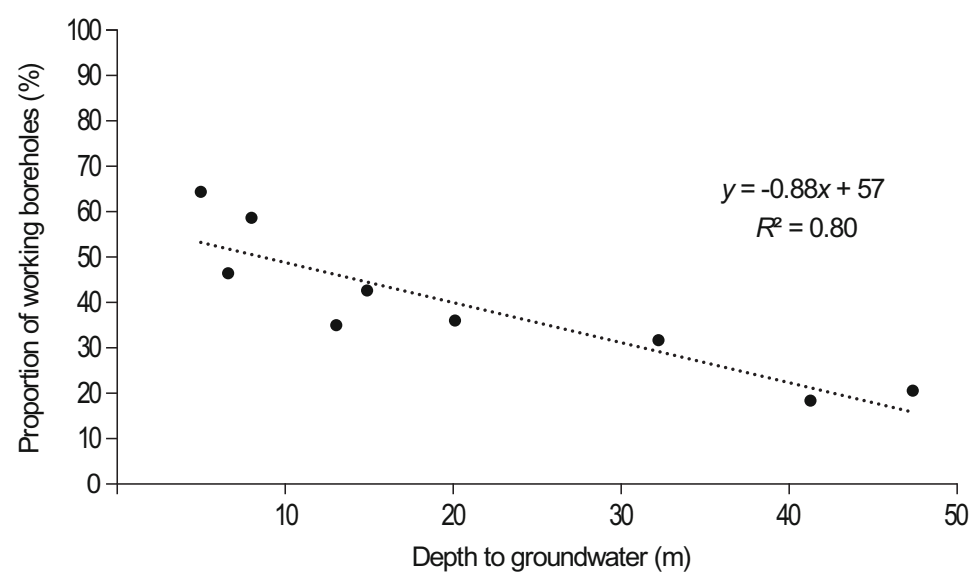

Fig. 5 a Specific capacity measured in 2012. b Percentiles of normalised specific capacity with depth. c Mean depth to groundwater at the time of surveying (September 2014 to March 2015) vs. percentage of working boreholes for each village. RWL rest water level

based on NOAA northern hemisphere values (NOAA 2019), i.e. modern fractions were consistently $>1$ (ESM2), likely due to geogenic sources of contamination (Lapworth et al. 2015). The excess CFCs could either be attributed to a local atmospheric input (e.g. Montzka et al. 2018), or could be due to diffuse, low level contamination of the subsurface from anthropogenic waste such as refrigerants (e.g. Darling et al. 2010). Together, these results show that the residence time tracers are not suitable for quantitative estimates of groundwater mean residence time, but instead can be used in a qualitative tracer of modern recharge within the groundwater system. A weak positive correlation between CFC-12 and $\mathrm{NO}_{3}$ is shown in Fig. 7b, subplot, which demonstrates that both tracers are present in higher concentrations in samples with a greater component of modern recharge irrespective of borehole depth.

Stable isotope results are summarised as a cross plot of $\delta^{18} \mathrm{O}$ vs. $\delta^{2} \mathrm{H}$ for groundwater and rainfall in relation to the local (LMWL) and global meteoric water lines (Fig. 7c) and $\delta^{18} \mathrm{O}$ vs. d-excess (Fig. $7 \mathrm{~d}$ ). The isotopic enrichment of $\delta^{18} \mathrm{O}$ 
Fig. 6 Fracture depth, total groundwater flow within the boreholes and flows into and out of the boreholes identified through dilution test modelling. Locations of boreholes in Fig. 1a

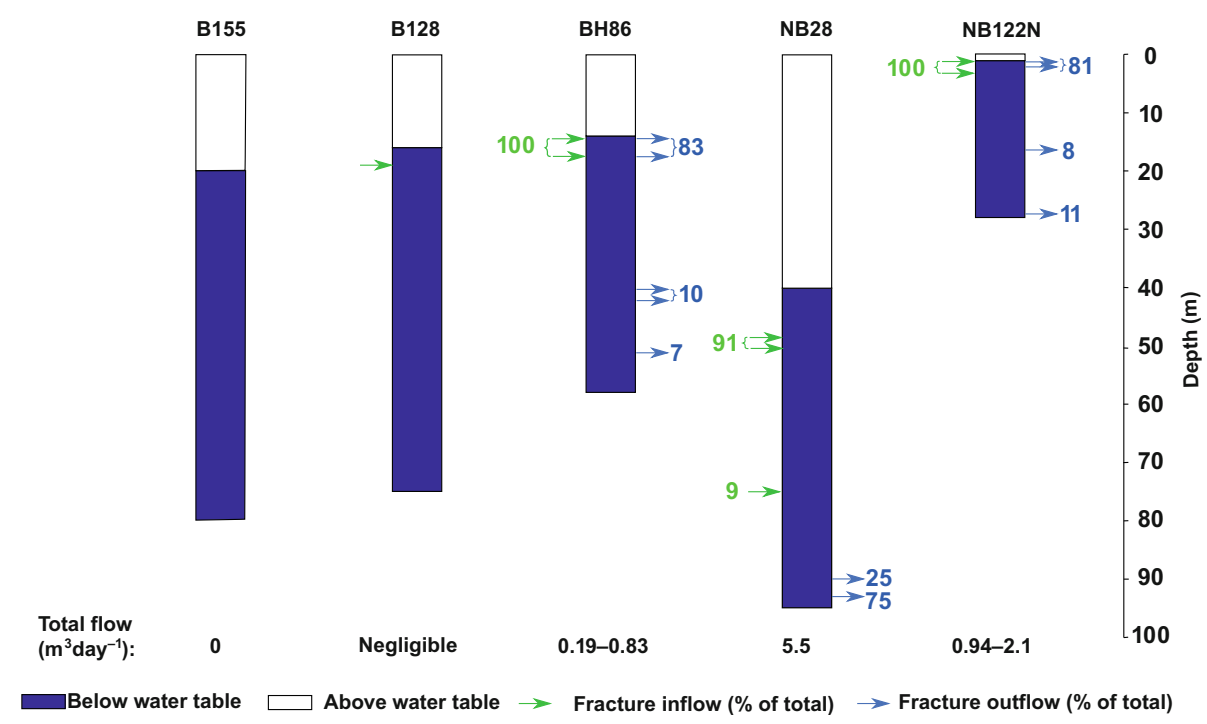

in groundwater relative to $\delta^{2} \mathrm{H}$ compared to the LMWL, i.e. lower slope for groundwater's (Fig. 7c) and d-excess values consistently below $10 \%$ (Fig. 7d) clearly show the effect of evaporative enrichment of rainfall prior to groundwater recharge. The groundwater isotope signatures are tightly clustered for both pre- and post-monsoon sampling (Fig. 7c); however, post-monsoon d-excess values are on average $2 \%$ o lower in the post-monsoon samples relative to pre-monsoon, evidence that there is a rapid recharge component within the overall highly mixed groundwater system.

\section{Numerical transect model}

Figure 8 shows the results of the transient simulations; the hydrographs represent an average for each transmissivity profile for the range of abstractions considered, using a specific yield of $0.27 \%$. The transmissivity profiles at the 10th and 25 th percentiles failed to meet the calibration criterion in the steady-state model and are therefore excluded from Fig. 8. This is perhaps to be expected when scaling up from the borehole scale: Le Borgne et al. (2006) found that transmissivity converged towards the highest values of their transmissivity distribution at larger scale in crystalline basement rock. The best values of specific yield were consistently between 0.2 and $0.4 \%$, which corresponds with magnetic resonance sounding carried out in a neighbouring catchment, which showed an effective porosity of $1 \%$ in the regolith/saprolite and an effective porosity below detection limit in the fractured rock $(<0.5 \%$; Legchenko et al. 2006). Decreasing specific yield exponentially with depth to reflect the decrease in transmissivity failed to improve either the root mean square error (RMSE) or Nash-Sutcliffe efficiency of the model results.

Overall, the simulated groundwater levels are a good fit to the observations (RMSE of 5.8-7.5 m; uncertainty in observations due to uncertainty in ground elevation $\pm 5 \mathrm{~m}$ ), suggesting that the equivalent porous medium approach used here is appropriate for use in this highly fractured gneiss aquifer. It also suggests that, despite heterogeneity in the geology, there is good lateral connectivity along the transect. Although recharge was not increased underneath the tanks in the model (based on isotopic evidence, see ESM1), both tanks provide significant net recharge to the system because groundwater abstraction does not occur within the tanks (see 4,250 and 7,750 $\mathrm{m}$ in Fig. 8).

Figure 9a shows the mean water balance for all transient simulations (with specific yield $=0.27 \%$ ). It excludes the easternmost $1.25 \mathrm{~km}$ of the transect to avoid effects of the boundary condition, particularly in the first year when there is a large shift from the constant head imposed during the steady-state simulation (initial condition) and the heads imposed during the first year. The availability of water in the catchment is controlled by the rainfall volume and abstraction, with lateral groundwater flow out of the catchment and baseflow comprising only a small part of the water balance, even with the highest transmissivity values (90th percentile, represented in error bars). Baseflow is particularly low and only occurs in 3 of the 9 years simulated. High and uniform abstraction results in little net recharge and shallow hydraulic gradients (mean gradient of -0.006 for median transmissivity profile), and therefore limited lateral flow down the transect.

Figure $9 \mathrm{~b}, \mathrm{c}$ shows the water balance for the simulations of reduced abstraction using the median transmissivity profile. The water balance is calculated for the first $10 \mathrm{~km}$ of the transect, as in Fig. 9a. The simulations with low and no abstraction (Fig. 9b, c) raise groundwater levels and increase lateral groundwater flow. The volume of water leaving the catchment as lateral groundwater flow remains relatively constant; however, groundwater becomes reconnected to the river 

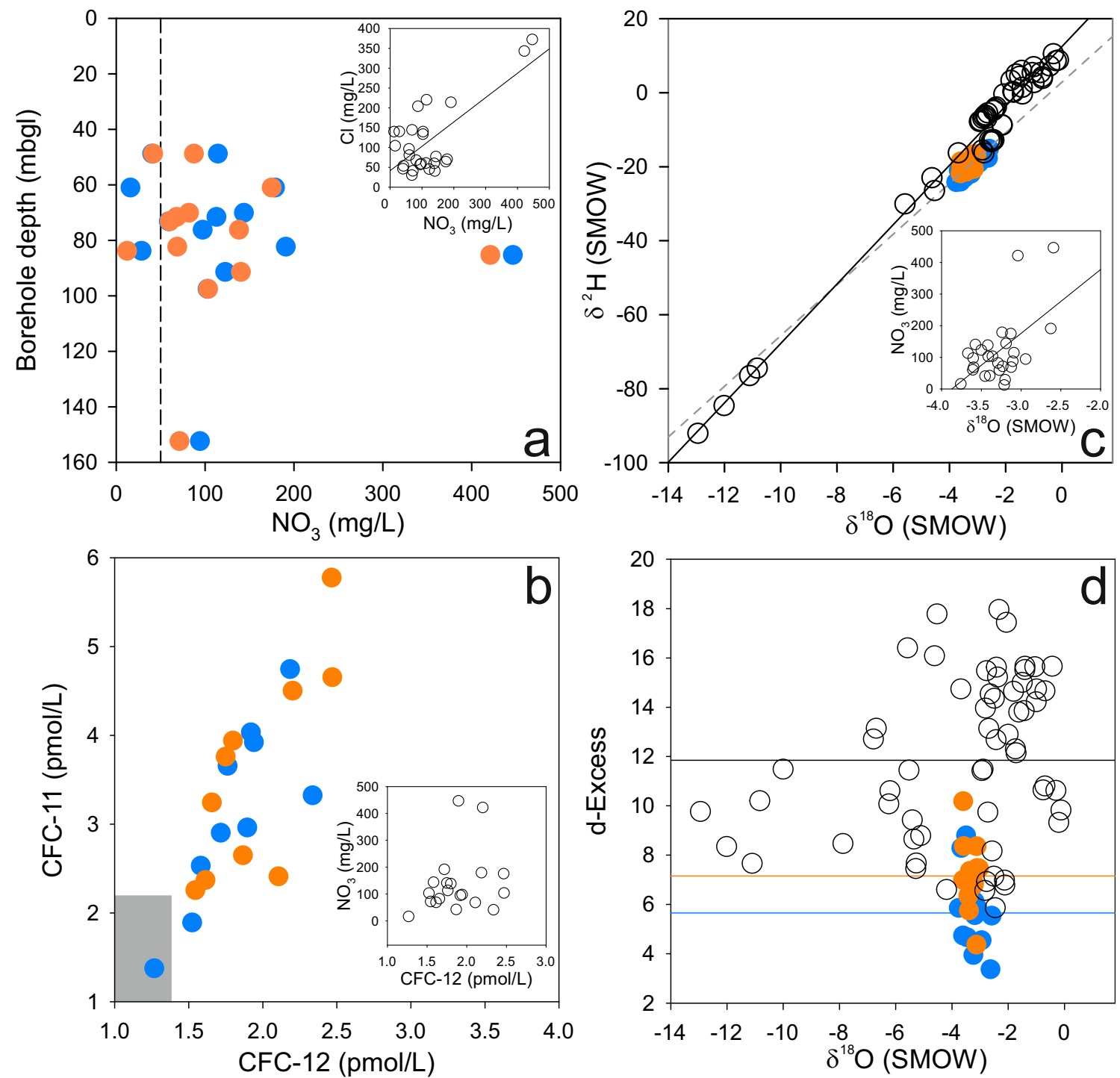

Fig. 7 Hydrochemical tracer results for groundwater and rainfall samples. a Cross plot of groundwater $\mathrm{NO}_{3}$ vs. borehole depth, dashed vertical line shows WHO drinking water limit of $50 \mathrm{mg} / \mathrm{L} \mathrm{NO}_{3}$, filled blue symbols show post-monsoon data (2017), filled orange symbols show premonsoon data (2018), subplot of groundwater $\mathrm{NO}_{3}$ vs. $\mathrm{Cl}$ with linear regression line, $\mathbf{b}$ cross plot of groundwater CFC-12 vs. CFC-11, grey box shows boundary of expected modern recharge values for CFCs based on northern hemisphere atmospheric concentrations (NOAA 2019),

bed and baseflow increases significantly with, for example, the mean increasing from 2 to 32,49 and $66 \mathrm{~mm} /$ year for the median transmissivity profile.

\section{Discussion}

Results from hydrogeological investigations and the numerical model have been jointly analysed to better understand the structure of the fractured gneiss aquifer in the Berambadi catchment.

subplot of groundwater CFC-12 vs. $\mathrm{NO}_{3}$, c Cross plot of $\delta^{18} \mathrm{O}$ vs. $\delta^{2} \mathrm{H}$ for groundwater (filled symbols) and rainfall (open symbols), solid line shows local meteoric water line, dashed line shows global metioric water line for reference, subplot of groundwater $\delta^{18} \mathrm{O} v \mathrm{vs} \mathrm{NO}_{3}$ with regression fit, $\mathbf{d}$ Cross plot of $\delta^{18} \mathrm{O}$ vs. d-excess for groundwater and rainfall, horizontal lines show average results for rainfall (black line), 2018 premonsoon groundwater (orange line) and 2017 post-monsoon groundwater (blue line)

\section{Three-dimensional (3D) aquifer properties of the sheared gneiss}

A hydrogeological conceptual model of highly sheared gneiss is given in Fig. 10 and summarised in Table 2. High normalised specific capacity values within the top $20 \mathrm{~m}$ suggest that the saprock and the top 5-10 m of gneiss, comprising welldeveloped subhorizontal sheet joints, form a well-connected fracture network with high hydraulic conductivity. Hydraulic conductivity does not decrease as significantly with depth as has been found in other crystalline basement rocks: for example, hydraulic conductivity decreases from $0.35 \mathrm{~m} /$ day $(0.07$ 


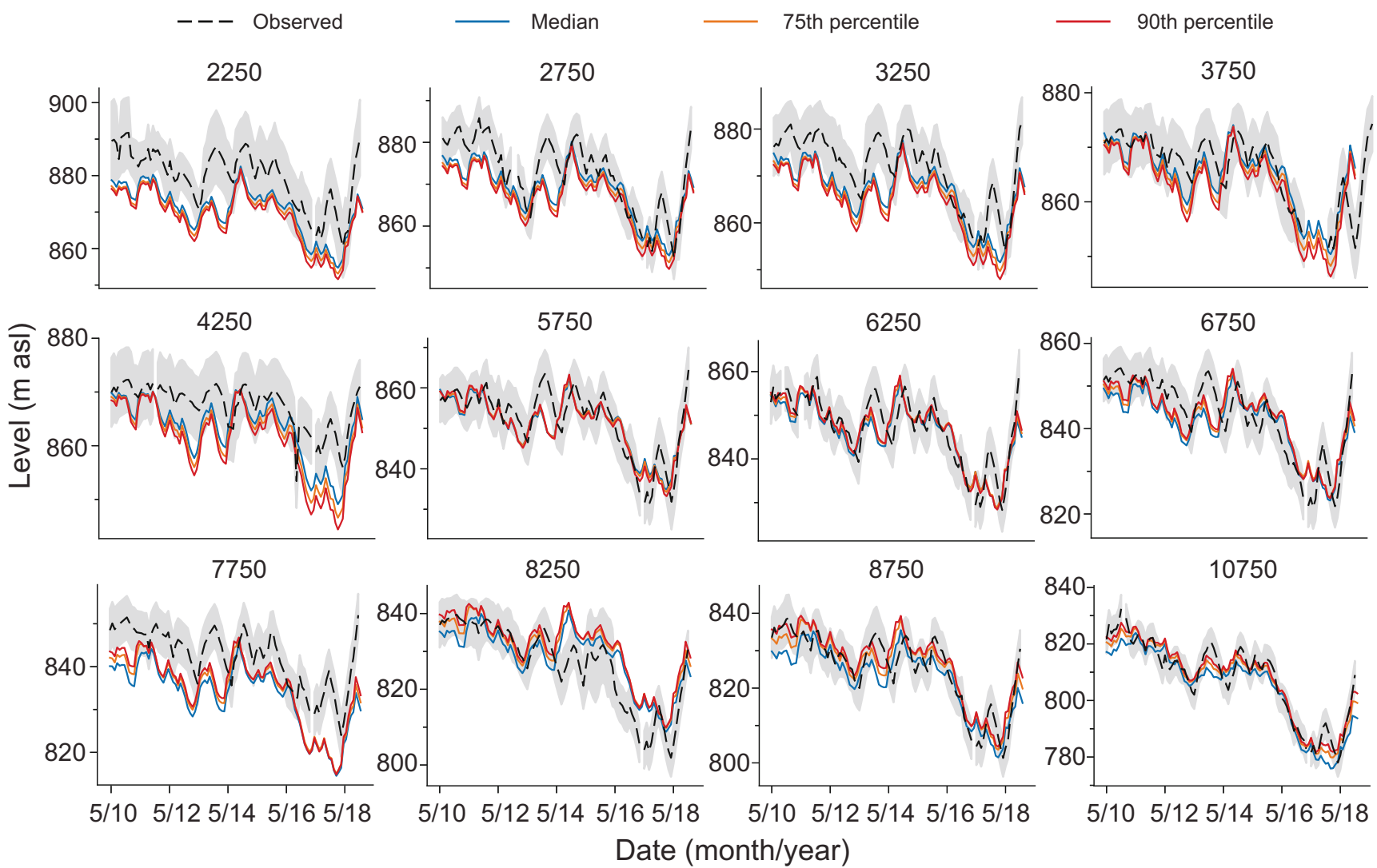

Fig. 8 Observed and simulated groundwater levels. Number above each figure is distance $(\mathrm{m})$ along transect from northwest to southeast. Grey shading represents uncertainty in observations (see ESM1). asl above sea level

$1.34 \mathrm{~m} /$ day, 10-90th percentile) at rest water level $<10 \mathrm{~m}$ bgl to $0.20 \mathrm{~m} /$ day $(0.05-0.60 \mathrm{~m} /$ day, $10-90$ th percentile) at rest water level $20-40 \mathrm{~m} \mathrm{bgl}$, which is far less than the orders of magnitude change in hydraulic conductivity in Dewandel et al.'s (2006) conceptual model of granite aquifers. This is also compatible with the work of Maréchal et al. (2010), who found a linear decrease in transmissivity with depth to rest water level between 5 and $25 \mathrm{~m} \mathrm{bgl}$ in a borehole to the north of the Berambadi. This is consistent with geological observations of both vertical and horizontal fractures with a spacing of 1-3 m down to ca. $30 \mathrm{~m}$. Although geological observations were restricted to ca. $30 \mathrm{~m} \mathrm{bgl}$, the specific capacity and SBDT data suggest flow can also occur much deeper. The fractures with the highest flow rates in the SBDTs were found at 50 and $94 \mathrm{~m}$ below ground. Nevertheless, two of the five boreholes contained no or negligible ambient flow and survey results suggest $\sim 58 \%$ of boreholes drilled in the Berambadi have never produced water (691 of 1,192 boreholes). There is good correlation between percentage of working boreholes and depth to groundwater, suggesting that, once the saprock rock and highly fractured top of the gneiss have been dewatered, the probability of failure increases. It seems likely that geological heterogeneity in the horizontal direction as well as in the vertical direction, i.e. high conductivity shear zones vs. low conductivity strain zones, plays a role in borehole failure, in particular because the survey contains records of borehole failure in the 1970s, 1980s and 1990s, before widespread groundwater exploitation.

The total range in groundwater level over the monitoring period (2010-2018) is correlated with depth to groundwater, potentially reflecting a decrease in aquifer storage with depth. However, the results of the sensitivity analysis performed on the numerical model (see ESM1) suggest that any decrease in storage with depth is small between 10 and $60 \mathrm{~m} \mathrm{bgl,} \mathrm{which}$ could be a result of the deep sheering observed in the gneiss. Maréchal et al. (2010) were also unable to find a relationship between storage and water-table depth during hydraulic testing in a single borehole in the north of the catchment. The correlation between depth to groundwater and groundwater level range is more likely a consequence of the extent of groundwater use in irrigation (Fig. 1b; Robert et al. 2017).

\section{Evolution of groundwater connectivity and implications for baseflow}

Results from a suite of hydrochemical tracers reveal a similar groundwater composition across the catchment. The absence of clear changes in residence time tracers, $\mathrm{Cl}, \mathrm{NO}_{3}$ and stable isotopes in relation to depth or regional flow direction (with 
(b)

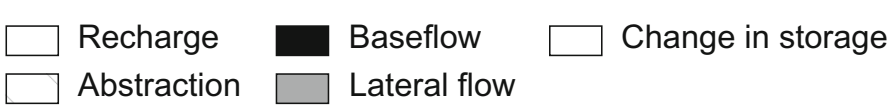

(a)
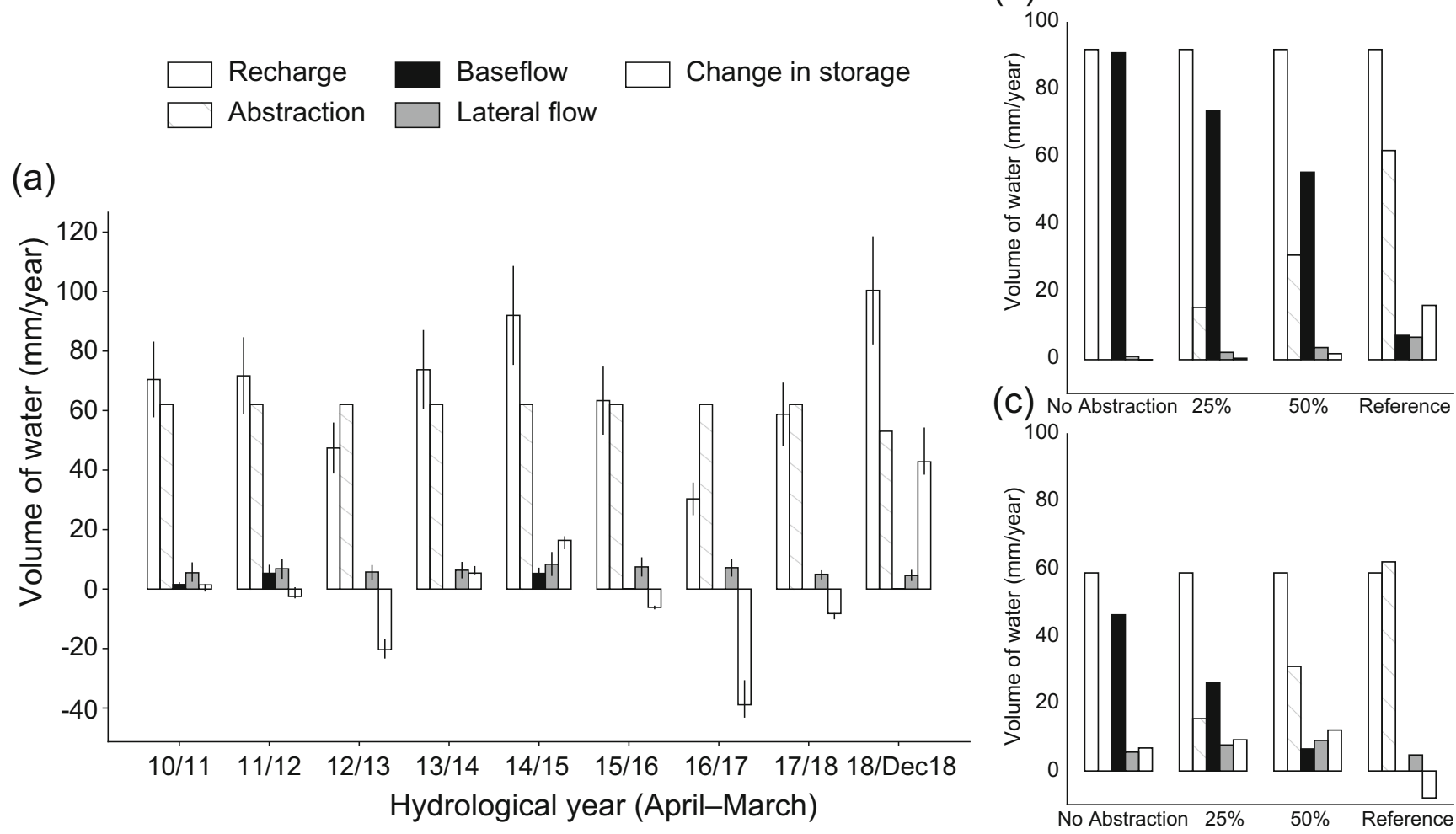

Fig. 9 a Mean groundwater balance for all transect models. Error bars represent minimum and maximum values from varying abstraction and transmissivity. Final year is only nine months, meaning abstraction and mean lateral flow are slightly lower than otherwise, but recharge is likely

representative of entire hydrological year. Water balance for simulations with reduced abstraction during $\mathbf{b}$ high water levels (14/15) and $\mathbf{c}$ low water levels $(17 / 18)$

the exception of $\mathrm{NO}_{3}$ ) within the sampling network suggests limited lateral flow within the aquifer system (Fig. 7). The spatial variations in $\mathrm{NO}_{3}$ across the catchment are a reflection of the historical evolution of agriculture, and hence fertiliser use, in the catchment and the development of groundwater irrigation (Buvaneshwari et al. 2017). The uniformity of the groundwater composition for multiple tracers indicates that this is a well-mixed groundwater system, with no clear vertical stratification in the saturated zone, and hence vertical flow dominates over lateral flow. This contrasts with studies undertaken in the forested part of the Kabini catchment (Maréchal et al. 2009) and other studies in basement terrains in catchments with no groundwater pumping (e.g. Soulsby et al. 1998; Shand et al. 2005; Lapworth et al. 2008), where a more clearly stratified and highly heterogeneous groundwater hydrochemistry is observed. The high concentrations of contemporary recharge tracers (nitrate and CFCs) at all depths evidence strong vertical connectivity; likewise, the small shift in isotopic composition (lower d-excess) in post-monsoon relative to pre-monsoon groundwater suggests a system with high vertical hydraulic connectivity leading to rapid replenishment to considerable depth ( $>80 \mathrm{~m} \mathrm{bgl}$ ) within the groundwater system during the 2017 monsoon. It should be noted, however, that the hundreds of uncased boreholes in the catchment act as vertical conduits and potentially add significantly to the vertical connectivity of the natural fracture network. These findings corroborate those of Shivanna et al. (2004), who attributed this shift to lower d-excess in post-monsoon groundwater to rainfall from the north-east monsoon, which has an isotopically depleted signature due to the interaction of dry air masses which pick up moisture under reduced relative humidity in the Bay of Bengal.

The most likely explanation for the high vertical connectivity and uniformity in groundwater composition is the overriding influence of pumping-induced changes in head gradients from boreholes across the catchment and the highly dynamic groundwater levels as a results of low storage within the system. This is consistent with the conceptual model in which the aquifer system evolves from a shallow laterally connected system under high (natural) groundwater level conditions towards a more compartmentalised systems as a result of abstraction. This conceptual model is further supported by the numerical groundwater model, which suggests that abstraction and changes in storage are much more significant components of the groundwater balance than lateral groundwater flow or baseflow. These findings are compatible with results from earlier hydrochemical studies in the fractured granitic setting in India with intense pumping (e.g. Perrin et al. 2011b; Guihéneuf et al. 2014; Pauwels et al. 2015). 


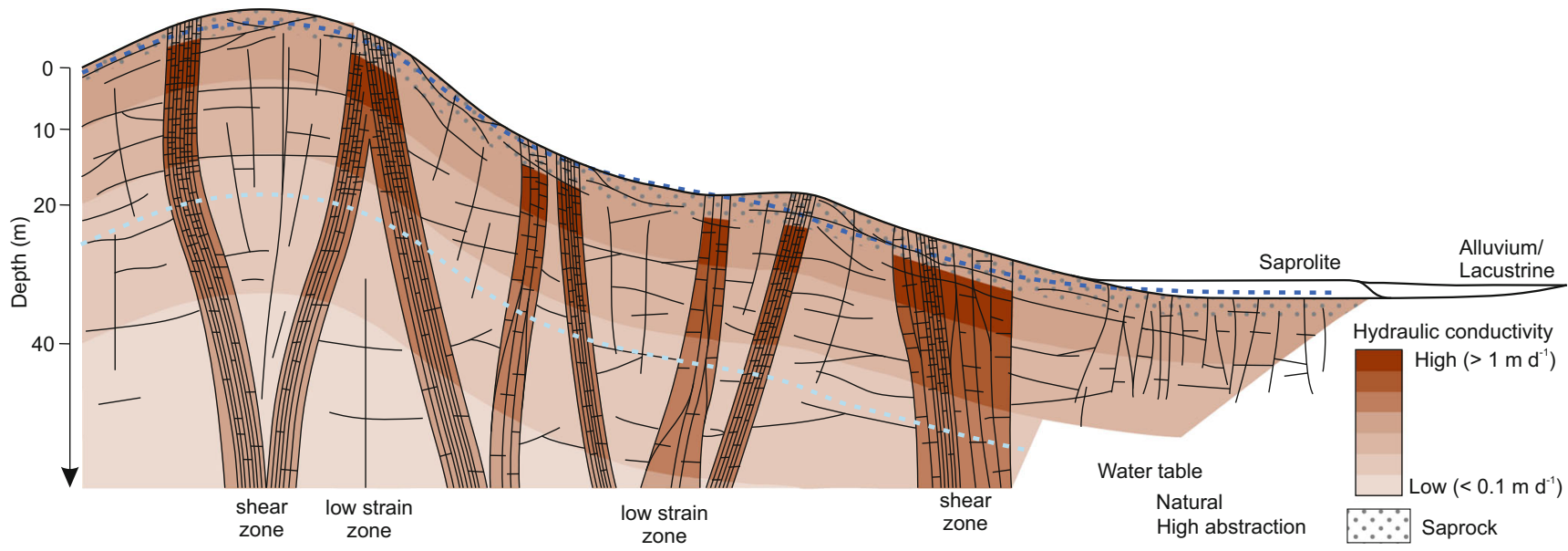

Fig. 10 Conceptual model of highly sheared gneiss in peninsular India both under natural conditions (no pumping) and subject to intensive/high abstraction

The findings from our study, and others mentioned above, to some extent contrast with those of Sukhija et al. (2006) and Reddy et al. (2009), who found groundwater ages of $>1,300$ years at selected sites/depths and a systematic variation of hydrochemistry with groundwater flow direction and age in over-exploited granitic terrains near Hyderabad. However, their analysis still points to a largely laterally compartmentalised flow system, albeit with an apparently isolated network of fractures containing much older groundwater based on stable isotope, $\mathrm{Cl}$ and radiocarbon dating.

The evaporative enrichment in groundwater samples relative to rainfall and the ubiquitously high nitrate, and CFC tracer composition "above modern" recharge concentrations (Fig. S7 of ESM1), also potentially points to the recycling of shallow groundwater recharge as a result of pumping and irrigation (e.g. Perrin et al. 2011b; Foster

Table 2 Aquifer characterisation

\begin{tabular}{|c|c|c|c|c|}
\hline Parameter & Value/description & Spatial variation & Depth variation & Source of evidence \\
\hline Shearing & $\begin{array}{l}\text { Strongly developed gneissosity, } \\
\text { intense horizontal and vertical } \\
\text { fracturing }\end{array}$ & $40-70 \%$ of the catchment & Unknown & GOs \\
\hline \multicolumn{5}{|l|}{ Weathering profile } \\
\hline Saprolite & $1-3 \mathrm{~m}$ thick $(<0.5 \mathrm{~m}$ on slopes $)$ & $\begin{array}{l}\text { Absent or thin on slopes, } \\
\text { thicker in valley }\end{array}$ & - & GOs \\
\hline Saprock & $1-3 \mathrm{~m}$ thick & Always present & - & GOs \\
\hline Bedrock & $\begin{array}{l}\text { Horizontal fractures } 1 \text { to }>12 \mathrm{~m} \text { in } \\
\text { length, vertical fractures }<1 \mathrm{~m} \\
\text { in length, flowing fractures } \\
\text { observed to } 94 \mathrm{~m} \mathrm{bgl}\end{array}$ & $\begin{array}{l}\text { Fracturing more intense in } \\
\text { shear zones }\end{array}$ & $\begin{array}{l}\text { Spacing of horizontal } \\
\text { fractures } 1-2 \mathrm{~m} \text { in top } \\
5-10 \mathrm{~m}, 1-3 \mathrm{~m} \text { in } \\
\text { next } 10-30 \mathrm{~m}\end{array}$ & GOs, SBDTs \\
\hline \multicolumn{5}{|c|}{ Hydrodynamic parameters } \\
\hline Specific capacity & $\begin{array}{l}0.9-48 \mathrm{~m}^{2} / \text { day, } 0.02-1.1 \mathrm{~m}^{2} / \\
\text { day } / \mathrm{m} \text { (normalised) }\end{array}$ & $\begin{array}{l}\text { Spatially variable but no } \\
\text { systematic variation other } \\
\text { than in relation to water-table } \\
\text { depth (Fig. } 5 \mathrm{a}, \mathrm{b})\end{array}$ & $\begin{array}{l}\text { Exponential decrease } \\
\text { with depth }\end{array}$ & Specific capacity test \\
\hline Transmissivity & $1-60 \mathrm{~m}^{2} /$ day $^{\mathrm{a}}$ & $\begin{array}{l}\text { Spatially variable but no } \\
\text { systematic variation other } \\
\text { than in relation to } \\
\text { water-table depth (Fig. } 5 \mathrm{a}, \mathrm{b})\end{array}$ & $\begin{array}{l}\text { Exponential decrease } \\
\text { with depth }\end{array}$ & $\begin{array}{l}\text { Specific capacity test, } \\
\text { Logan (1964) } \\
\text { empirical model }\end{array}$ \\
\hline Specific yield & $\sim 0.2-0.4 \%$ & Unknown & $\begin{array}{l}\text { Potentially little variation } \\
10-60 \mathrm{~m} \mathrm{bgl}\end{array}$ & $\begin{array}{l}\text { Numerical model, see also } \\
\text { Legchenko et al. (2006) }\end{array}$ \\
\hline Recharge & $\begin{array}{l}\sim 30-100 \mathrm{~mm} / \mathrm{year}, 5-9 \% \text { of } \\
\quad \text { rainfall }\end{array}$ & No spatial variation & No vertical stratification & $\begin{array}{l}\text { Stable isotopes, } \\
\text { numerical model }\end{array}$ \\
\hline
\end{tabular}

${ }^{\text {a }}$ Ranges represent 10-90th percentiles

bgl below ground level; GOs geological observations; SBDT single-borehole dilution test 
et al. 2018). This is supported by the fact that there is an overall positive relationship between TDS and CFC-12, which is clearer for the post-monsoon 2017 data than for pre-monsoon in 2018 (Fig. S8 of ESM1); however, overall, the correlation is very weak and not statistically significant. The lack of a strong correlation is not surprising due to the fact that the enriched recycled component flushed into the aquifer during the monsoon will only be a minor contribution to groundwater and mixing processes within the aquifer and borehole will tend to obscure seasonal differences. The fact that this seasonal difference was observed at all may be due to the fact that rainfall totals during the previous two monsoons (2016 and 2017) were low relative to recent records, and evaporation and irrigation returns due to pumping are likely to have increased during this period (Fig. 4).

In a study near Hyderabad, Guihéneuf et al. (2014) showed how the general groundwater flow direction on a watershed scale was lost when groundwater levels dropped and the saprolite became dewatered, the saprolite being much thicker in Hydrabad $(>10 \mathrm{~m}$ ) than in the Berambadi (typically $<1 \mathrm{~m}$ ). In the Berambadi, however, groundwater levels show a very strong uniformity (Fig. 4a) and, even when groundwater levels were $20-60 \mathrm{~m} \mathrm{bgl}$, the general flow direction was preserved (Fig. S4 of ESM1). The contrast between these two aquifers can also be seen in the variograms plotted at high and low water level (compare Fig. 4c and Fig. 13 in Guihéneuf et al. 2014); whereas in the Hyderbad study, low groundwater levels were spatially correlated over only $\sim 200 \mathrm{~m}$, in the Berambadi there is a clear spatial correlation across the catchment at both high and low groundwater levels. The geological differences - granite vs. sheared gneiss - and resulting differences in fracture networks may explain the greater lateral connectivity found in the Berambadi. However, it cannot be ruled out that the difference is simply a scale effect (Hydrabad watershed $3 \mathrm{~km}^{2}$ vs. Berambadi $84 \mathrm{~km}^{2}$ ) and that, if the Hyderabad study were repeated over a larger area, the results would be similar.

The numerical model indicates that, if abstraction were reduced in the catchment, groundwater levels would rise, potentially reconnecting the aquifer with the surface. Lateral groundwater flow increased as a result of reducing abstraction, but only as far as topographic depressions, where it emerged to produce baseflow, even in dry years. A possible implication of this is that, even in densely fractured gneiss, lateral groundwater flow may be unimportant in large-scale modelling or, at least, less important than an accurate model of topography.

\section{Abstraction, the seasonal monsoon cycle and groundwater resilience}

The similarity of groundwater hydrochemistry across the catchment suggests vertical flow dominates over lateral flow and recharge to the system is distributed with no clear recharge or discharge zones. It could be that the high fracture density at shallow depths and the thin to absent saprolite layer aid good lateral dispersion of recharge flow. The system can both become severely stressed and recover from severe stress in a very short space of time. During periods of low rainfall, groundwater levels can drop tens of metres in just 2 years, restricting borehole yields and causing borehole failure. However, groundwater levels and borehole yields can also recover in as little as a year, showing a much faster recovery than would be expected, for example, from alluvial aquifers in northern India.

There remains a high level of uncertainty in how the Indian summer monsoon will evolve with climate change (e.g. Turner and Annamalai 2012; Dessai et al. 2018). It has been speculated, however, that the frequency of both strong and weak monsoons may increase significantly in the future (Sharmila et al. 2015). It is therefore encouraging to observe that rapid recovery of groundwater levels is possible, as groundwater's role as a buffer to low rainfall may become even more important in the future. There is anecdotal evidence of farmers planting more water-intensive crops when groundwater levels are high, suggesting that the lack of a reliable water resource necessitates a more flexible agricultural system. This is consistent with the work of Fishman et al. (2011), who found a deeper water-table pregrowing season was correlated with reduced cultivation of rice and other irrigated crops in Telangana, in south-central India.

\section{Conclusion}

Connectivity of groundwater flow within crystalline-rock aquifers controls the sustainability of abstraction, baseflow to rivers and the transport of solutes. Geological characterisation, aquifer properties testing, hydrograph analysis and hydrochemical tracer analysis have been carried out, and a numerical groundwater flow model built, in order to investigate groundwater connectivity of a sheared gneiss aquifer. The study indicates the top $20 \mathrm{~m}$ of the aquifer comprises a well-connected fracture network with high hydraulic conductivity. Likely as a result of shearing, hydraulic conductivity does not appear to decrease with depth as significantly as has been found in other granite-dominated crystalline-basement rocks and a degree of lateral connectivity remains even at low water levels. The aquifer appears well connected, both laterally and vertically, although hydrochemical tracers suggest high abstraction has resulted in a change from a laterally to a vertically dominated flow system. The fracture networks of different crystalline-rock aquifers vary significantly, but hydrogeologists tend to use the same conceptual model (Dewandel et al. 2006) for all rock types. This study provides evidence for a new hydrogeological conceptual model of sheared gneiss. Further research applying the same techniques to different crystalline-rock aquifers at the same scale could 
determine how many different typologies exist, which could lead to better modelling and management of these aquifers.

Because of their low storage and exponential decrease in hydraulic conductivity with depth, crystalline-rock aquifers in environments such as this, with high abstraction and seasonal recharge, constitute a highly variable water resource, providing farmers with a buffer for low rainfall for 1-3 consecutive years. Moreover, in periods of both high and low water levels, this study indicates that abstraction is restricting baseflow to the river. This will have implications downstream in the Cauvery River Basin, if also occurring in other similar catchments.

Acknowledgements The views and opinions expressed in this paper are those of the authors alone. The authors would like to thank Carole Arrowsmith and Melanie Leng for stable isotope analysis, Gopal Penny for providing rainfall stable isotope data, P.R. Giriraja for collecting groundwater levels, and Calum Ritchie and Ian Longhurst for help in producing the figures.

Funding information The Kabini CZO is managed by the Indo-French Cell for Water Sciences. It is part of the Service National d'Observation (SNO) M-TROPICS, funded by the University of Toulouse, IRD and CNRS-INSU, and belongs to the French network of Critical Zone Observatories: Research and Application. These investigations contribute to a wider effort to understand hydrological flows, and the influence of small-scale interventions, across the Cauvery catchment, as the part of the UPSCAPE project. This evidence will contribute to improved and integrated water resource management across the catchment. The research underlying this paper was carried out under the UPSCAPE project of the Newton-Bhabha programme "Sustaining Water Resources for Food, Energy and Ecosystem Services", funded by the UK Natural Environment Research Council (NERC-UKRI) and the India Ministry of Earth Sciences (MoES), grant number(s) NE/N016270/1, MoES/NERC/ IA-SWR/P1/08/2016-PC-II (i) MoES/NERC/IA-SWR/P1/08/2016-PC-II (ii). SB acknowledges the HydroNation fellowship provided by the Scottish Government and James Hutton Institute. The British Geological Survey (BGS-UKRI) publish with the permission of the Director of BGS.

\section{Compliance with ethical standards}

\section{Conflict of interest None.}

Open Access This article is licensed under a Creative Commons Attribution 4.0 International License, which permits use, sharing, adaptation, distribution and reproduction in any medium or format, as long as you give appropriate credit to the original author(s) and the source, provide a link to the Creative Commons licence, and indicate if changes were made. The images or other third party material in this article are included in the article's Creative Commons licence, unless indicated otherwise in a credit line to the material. If material is not included in the article's Creative Commons licence and your intended use is not permitted by statutory regulation or exceeds the permitted use, you will need to obtain permission directly from the copyright holder. To view a copy of this licence, visit http://creativecommons.org/licenses/by/4.0/.

\section{References}

Acworth R (1987) The development of crystalline basement aquifers in a tropical environment. Q J Eng Geol Hydrogeol 20(4):265-272
Alazard M, Boisson A, Maréchal J-C, Perrin J, Dewandel B, Schwarz T, Pettenati M, Picot-Colbeaux G, Kloppman W, Ahmed S (2016) Investigation of recharge dynamics and flow paths in a fractured crystalline aquifer in semi-arid India using borehole logs: implications for managed aquifer recharge. Hydrogeol J 24(1):35-57

Buvaneshwari S, Riotte J, Sekhar M, Kumar MM, Sharma AK, Duprey JL, Audry S, Giriraja P, Praveenkumarreddy Y, Moger H (2017) Groundwater resource vulnerability and spatial variability of nitrate contamination: insights from high density tubewell monitoring in a hard rock aquifer. Sci Total Environ 579:838-847

Cai Z, Ofterdinger U (2016) Analysis of groundwater-level response to rainfall and estimation of annual recharge in fractured hard rock aquifers, NW Ireland. J Hydrol 535:71-84

CGWB (Central Ground Water Board) (2008) Groundwater information booklet: Chamarajnagar District, Karnataka. Ministry of Water Resources, Government of India, New Delhi

Chardon D, Jayananda M, Chetty TR, Peucat JJ (2008) Precambrian continental strain and shear zone patterns: south Indian case. J Geophys Res-Sol Ea 113:B8

Chilton PJ, Foster S (1995) Hydrogeological characterisation and watersupply potential of basement aquifers in tropical Africa. Hydrogeol $\mathrm{J}$ 3(1):36-49

Collins S, Bianchi M (2020) DISSOLV: a Python package for the interpretation of borehole dilution tests. Groundwater. https://doi.org/10. 1002/GWAT.12992

Comte J-C, Ofterdinger U, Legchenko A, Caulfield J, Cassidy R, González JM (2019) Catchment-scale heterogeneity of flow and storage properties in a weathered/fractured hard rock aquifer from resistivity and magnetic resonance surveys: implications for groundwater flow paths and the distribution of residence times. Geol Soc Lond Spec Publ 479(1):35-58

CWC-NRSC (Central Water Commission-National Remote Sensing Centre) (2014) Cauvery Basin, Version 2.0. Ministry of Water Resources, Gov. of India, New Delhi

Dansgaard W (1964) Stable isotopes in precipitation. Tellus 16(4):436468

Darling WG, Gooddy DC, Riches J, Wallis I (2010) Using environmental tracers to assess the extent of river-groundwater interaction in a quarried area of the English Chalk. Appl Geochem 25(7):923-932

Dessai S, Bhave AG, Birch C, Conway D, Garcia-Carreras L, Gosling JP, Mittal N, Stainforth D (2018) Building narratives to characterise uncertainty in regional climate change through expert elicitation (Sustainability Research Institute Working Paper 322). School of Earth and Environment, University of Leeds, Leeds, UK. http:// www.see.leeds.ac.uk/fileadmin/Documents/research/sri/ workingpapers/SRIPs-112.pdf . Accessed 18 February 2020

Dewandel B, Lachassagne P, Wyns R, Maréchal J, Krishnamurthy N (2006) A generalized 3-D geological and hydrogeological conceptual model of granite aquifers controlled by single or multiphase weathering. J Hydrol 330(1-2):260-284

Fishman RM, Siegfried T, Raj P, Modi V, Lall U (2011) Over-extraction from shallow bedrock versus deep alluvial aquifers: reliability versus sustainability considerations for India's groundwater irrigation. Water Resour Res 47:W00L05

Foster S, Pulido-Bosch A, Vallejos Á, Molina L, Llop A, MacDonald AM (2018) Impact of irrigated agriculture on groundwater-recharge salinity: a major sustainability concern in semi-arid regions. Hydrogeol J 26(8):2781-2791

Guihéneuf N, Boisson A, Bour O, Dewandel B, Perrin J, Dausse A, Viossanges M, Chandra S, Ahmed S, Maréchal J (2014) Groundwater flows in weathered crystalline rocks: impact of piezometric variations and depth-dependent fracture connectivity. J Hydrol 511:320-334

Hora T, Srinivasan V, Basu NB (2019) The groundwater recovery paradox in South India. Geophys Res Lett 46. https://doi.org/10.1029/ 2019GL083525 
IAEA/GNIP (2014) International Atomic Energy Agency/Global Network of Isotopes in Precipitation: precipitation sampling guide. http://www-naweb.iaea.org/napc/ih/documents/other/gnip manual_v2.02_en_hq.pdf. Accessed 1 July 2019

IFCWS (2019) Kabini River Basin. Indo French cell for water sciences. http://www.cefirse.ird.fr/content/view/full/84031. Accessed 2 April 2019

IISc (Indian Institute of Sciences) (2019) Assimilation of multi satellite data at the Berambadi Watershed for Hydrology and Land Surface experiment. http://ambhas.com/. Accessed 04 Spetember 2019

Jarvis A, Reuter HI, Nelson A, Guevara (2008) Hole-filled SRTM for the globe, version 4. http://srtm.csi.cgiar.org/. Accessed 18 February 2020

Kosugi KI, Katsura SY, Katsuyama M, Mizuyama T (2006) Water flow processes in weathered granitic bedrock and their effects on runoff generation in a small headwater catchment. Water Resour Res 42:2

Lachassagne P, Wyns R, Dewandel B (2011) The fracture permeability of hard rock aquifers is due neither to tectonics, nor to unloading, but to weathering processes. Terra Nova 23(3):145-161

Lapworth DJ, Shand P, Abesser C, Darling WG, Haria AH, Evans CD, Reynolds B (2008) Groundwater nitrogen composition and transformation within a moorland catchment, mid-Wales. Sci Total Environ 390(1):241-254

Lapworth DJ, MacDonald AM, Krishan G, Rao MS, Gooddy DC, Darling WG (2015) Groundwater recharge and age-depth profiles of intensively exploited groundwater resources in Northwest India. Geophys Res Lett 42(18):7554-7562

Le Borgne T, Bour O, Paillet F, Caudal J-P (2006) Assessment of preferential flow path connectivity and hydraulic properties at singleborehole and cross-borehole scales in a fractured aquifer. J Hydrol 328(1-2):347-359

Legchenko A, Descloitres M, Bost A, Ruiz L, Reddy M, Girard JF, Sekhar M, Mohan Kumar M, Braun JJ (2006) Resolution of MRS applied to the characterization of hard-rock aquifers. Groundwater 44(4):547-554

Logan J (1964) Estimating Transmissibility from Routine Production Tests of Water Wells. Ground Water 2(1):35-37

Maréchal J-C, Dewandel B, Ahmed S, Galeazzi L, Zaidi FK (2006) Combined estimation of specific yield and natural recharge in a semi-arid groundwater basin with irrigated agriculture. J Hydrol 329(1-2):281-293

Maréchal JC, Varma MR, Riotte J, Vouillamoz JM, Kumar MM, Ruiz L, Sekhar M, Braun JJ (2009) Indirect and direct recharges in a tropical forested watershed: mule hole. India J Hydrol 364(3-4):272-284

Maréchal J-C, Vouillamoz J-M, Mohan Kumar MS, Dewandel B (2010) Estimating aquifer thickness using multiple pumping tests. Hydrogeol J 18(8):1787-1796

Maurice L, Barker J, Atkinson T, Williams A, Smart P (2011) A tracer methodology for identifying ambient flows in boreholes. Groundwater 49(2):227-238

Maurice L, Taylor R, Tindimugaya C, MacDonald A, Johnson P, Kaponda A, Owor M, Sanga H, Bonsor H, Darling W (2019) Characteristics of high-intensity groundwater abstractions from weathered crystalline bedrock aquifers in East Africa. Hydrogeol J 27(2):459-474

Meert JG, Pandit MK, Pradhan VR, Banks J, Sirianni R, Stroud M, Newstead B, Gifford J (2010) Precambrian crustal evolution of peninsular India: a 3.0 billion year odyssey. J Asian Earth Sci 39(6): 483-515

Montzka SA, Dutton GS, Yu P, Ray E, Portmann RW, Daniel JS, Kuijpers L, Hall BD, Mondeel D, Siso C, Nance JD (2018) An unexpected and persistent increase in global emissions of ozone-depleting CFC11. Nature 557(7705):413

Mukherjee A, Saha D, Harvey CF, Taylor RG, Ahmed KM, Bhanja SN (2015) Groundwater systems of the Indian sub-continent. J Hydrol: Reg Stud 4:1-14
Naqvi SM, Rogers JJW (1987) Precambrian geology of India. Oxford University Press, Oxford, UK

NOAA (National Oceanic and Atmospheric Administration) (2019) Halocarbons and other trace gases in the atmosphere. https://www. esrl.noaa.gov/gmd/hats/combined/CFC11.html. Accessed 01 July 2019

Ofterdinger U, MacDonald AM, Comte J-C, Young M (2019) Groundwater in fractured bedrock environments: managing catchment and subsurface resources: an introduction. Geol Soc Lond Spec Publ 479(1):1-9

Oster H, Sonntag C, Münnich KO (1996) Groundwater age dating with chlorofluorocarbons. Water Resour Res 32(10):2989-3001

Palamakumbura R, Krabbendam M, Whitbread K, Arnhardt C (2019) A review and evaluation of the methodology for digitising $2 \mathrm{D}$ fracture networks and topographic lineaments in GIS. Solid Earth Discuss. https://doi.org/10.5194/se-2019-184

Pauwels H, Négrel P, Dewandel B, Perrin J, Mascré C, Roy S, Ahmed S (2015) Hydrochemical borehole logs characterizing fluoride contamination in a crystalline aquifer (Maheshwaram, India). J Hydrol 525:302-312

Peel MC, Finlayson BL, McMahon TA (2007) Updated world map of the Köppen-Geiger climate classification. Hydrol Earth Syst Sci Discuss 4(2):439-473

Penny G, Srinivasan V, Dronova I, Lele S, Thompson S (2018) Spatial characterization of long-term hydrological change in the Arkavathy watershed adjacent to Bangalore. India Hydrol Earth Syst Sci Discuss 22:595-610

Penny G, Srinivasan V, Apoorva R, Peschel J, Young S, Thompson S (2019) A process-based approach to attribution of historical streamflow decline in a data-scarce and human-dominated catchment. Hydrol Process https://doi.org/10.1002/hyp.13707

Perrin J, Ahmed S, Hunkeler D (2011a) The effects of geological heterogeneities and piezometric fluctuations on groundwater flow and chemistry in a hard-rock aquifer, southern India. Hydrogeol J 19(6):1189

Perrin J, Mascré C, Pauwels H, Ahmed S (2011b) Solute recycling: an emerging threat to groundwater quality in southern India? J Hydrol 398(1-2):144-154

Rao RB (1962) A handbook of the geology of Mysore state, southern India. Bangalore Printing, Bangalore

Reddy D, Nagabhushanam P, Sukhija B, Reddy A (2009) Understanding hydrological processes in a highly stressed granitic aquifer in southern India. Hydrol Process 23(9):1282-1294

Robert M, Thomas A, Sekhar M, Badiger S, Ruiz L, Willaume M, Leenhardt D, Bergez JE (2017) Farm typology in the Berambadi watershed (India): farming systems are determined by farm size and access to groundwater. Water 9(1):51

Sekhar M, Riotte J, Ruiz L, Jourquet P, Braun JJ (2016) Influences of climate and agriculture on water and biogeochemical cycles: Kabini critical zone observatory. Proc Indian Nat Sci Acad 82:833-846

Shah T, Roy AD, Qureshi AS, Wang J (2003) Sustaining Asia's groundwater boom: an overview of issues and evidence. https:// onlinelibrary.wiley.com/doi/abs/10.1111/1477-8947.00048. Accessed March 2020

Shand P, Haria AH, Neal C, Griffiths KJ, Gooddy DC, Dixon AJ, Hill T, Buckley DK, Cunningham JE (2005) Hydrochemical heterogeneity in an upland catchment: further characterisation of the spatial, temporal and depth variations in soils, streams and groundwaters of the Plynlimon forested catchment Wales. Hydrol Earth Sys Sci 9(6): 621-644

Sharmila S, Joseph S, Sahai AK, Abhilash S, Chattopadhyay R (2015) Future projection of Indian summer monsoon variability under climate change scenario: an assessment from CMIP5 climate models. Glob Planet Chang 124:62-78 
Shivanna K, Kulkarni UP, Joseph TB, Navada SV (2004) Contribution of storms to groundwater recharge in the semi-arid region of Karnataka. India Hydrol Process 18(3):473-485

Sishodia RP, Shukla S, Graham WD, Wani SP, Garg KK (2016) Bidecadal groundwater level trends in a semi-arid south Indian region: declines, causes and management. J Hydrol 8:43-58

Sivakumar B (2011) Hydropsychology: the human side of water research. Hydrol Sci J 56(4):719-732

Soulsby C, Chen M, Ferrier RC, Helliwell RC, Jenkins A, Harriman R (1998) Hydrogeochemistry of shallow groundwater in an upland Scottish catchment. Hydrol Process 12(7):1111-1127

Srinivasan V, Thompson S, Madhyastha K, Penny G, Jeremiah K, Lele S (2015) Why is the Arkavathy River drying? A multiple-hypothesis approach in a data-scarce region. Hydrol Earth Syst Sci 19(4):19051917

Sukhija B, Reddy D, Nagabhushanam P, Bhattacharya S, Jani R, Kumar D (2006) Characterisation of recharge processes and groundwater flow mechanisms in weathered-fractured granites of Hyderabad (India) using isotopes. Hydrogeol J 14(5):663-674

Tiwari VM, Wahr JM, Swenson S, Singh B (2011) Land water storage variation over southern India from space gravimetry. Curr Sci 101(4):536-540
Tomer SK, Bitar AA, Sekhar M, Zribi M, Bandyopadhyay S, Kerr Y (2015) MAPSM: a spatio-temporal algorithm for merging soil moisture from active and passive microwave remote sensing. Remote Sens 8(12):990

Turner AG, Annamalai H (2012) Climate change and the south Asian summer monsoon. Nat Clim Chang 2:587-595

Vanham D, Weingartner R, Rauch W (2011) The Cauvery river basin in southern India: major challenges and possible solutions in the 21 st century. Water Sci Technol 64(1):122-131

World Bank (2010) Deep wells and prudence: towards pragmatic action for addressing groundwater overexploitation in India. Deep wells and prudence: towards pragmatic action for addressing groundwater overexploitation in India. Report no. 51676, World Bank, Washington, DC

Wyns R, Baltassat J-M, Lachassagne P, Legchenko A, Vairon J, Mathieu F (2004) Application of proton magnetic resonance soundings to groundwater reserve mapping in weathered basement rocks (Brittany, France). Bull Soc Géol France 175(1):21-34

Zhao S, Hu H, Harman CJ, Tian F, Tie Q, Liu Y, Peng Z (2019) Understanding of storm runoff generation in a weathered, fractured Granitoid headwater catchment in northern China. Water 11(1):123 